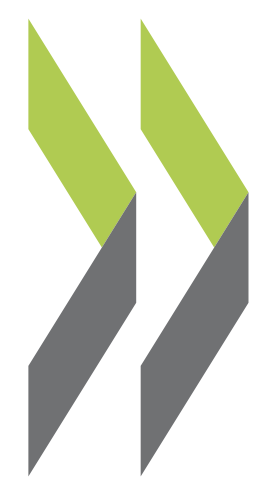

OECD Economics Department Working Papers No. 1021

\section{Education Quality and Labour Market}

Outcomes in South Africa
Nicola Branson,

\section{Murray Leibbrandt}


Organisation de Coopération et de Développement Économiques

Organisation for Economic Co-operation and Development

18-Feb-2013

ECONOMICS DEPARTMENT

English - Or. English

EDUCATION QUALITY AND LABOUR MARKET OUTCOMES IN SOUTH AFRICA

ECONOMICS DEPARTMENT WORKING PAPERS No. 1021

by Nicola Branson and Murray Leibbrandt

All Economics Department Working Papers are available through OECD's Internet website at www.oecd.org/eco/workingpapers

JT03334769

Complete document available on OLIS in its original format

This document and any map included herein are without prejudice to the status of or sovereignty over any territory, to the delimitation of international frontiers and boundaries and to the name of any territory, city or area. 


\section{ABSTRACT/RÉSUMÉ \\ Education quality and labour market outcomes in South Africa}

In this Paper we include measures of school quality in regressions determining the labour market premiums to education level. We use the matric exemption score and the pupil/teacher ratio of the respondents' closest school during childhood as proxies for education quality. We find that the employment and earnings premiums to education level are robust to the inclusion of these quality measures. Moreover, there is a significant direct relationship between our quality measures and earnings, controlling for education level. Increasing the matric exemption score by 10 percentage points increases earnings, on average, by $8 \%$ and decreasing the pupil/teacher ratio by one learner is associated with a $1 \%$ increase in earnings. No significant relationship is found between the school quality measures and employment.

This Working Paper relates to the 2013 OECD Economic Survey of South Africa, www.oecd.org/eco/surveys/listofeconomicsurveysofsouthafrica.htm.

JEL codes: $\mathrm{I} 24 ; \mathrm{J} 21 ; \mathrm{J} 31$

Keywords: earnings; employment; education; education quality; South Africa

\section{Qualité de l'éducation et rendement sur le marché du travail en Afrique du Sud}

Dans cette étude nous incluons des variables de qualité de l'éducation dans les régressions déterminant le rendement sur le marché du travail des niveaux d'éducation atteints. En guise de mesure de la qualité, nous utilisons le taux de réussite au diplôme final d'études secondaires ainsi que le ratio élève/enseignant de l'école la plus proche du lieu de résidence de l'individu sondé durant sa jeunesse. Nous trouvons que les effets des niveaux éducatifs sur les salaires et les probabilités d'avoir un emploi sont robustes à l'inclusion de ces variables de qualité de l'éducation. De plus, il y a une relation directe significative entre nos variables de qualité et les salaires après contrôle pour le niveau éducatif atteint. Augmenter le taux de réussite de l'école de 10 points de pourcentage augmente les salaires d'en moyenne $8 \%$, tandis que diminuer le ratio élève-enseignant d'un élève augmente les salaires de $1 \%$. Aucune relation robuste n'est exhibée entre les mesures de qualité de l'éducation et l'emploi.

Ce Document de travail se rapporte à l'Étude économique de l'OCDE de l'Afrique du Sud, www.oecd.org/fr/eco/etudeseconomiquesparpays/listofeconomicsurveysofsouthafrica.htm.

Classification JEL: I24; J21; J31

Mots clés: salaire ; emploi ; éducation ; qualité de l'éducation ; Afrique du Sud

You can copy, download or print OECD content for your own use, and you can include excerpts from OECD publications, databases and multimedia products in your own documents, presentations, blogs, websites and teaching materials, provided that suitable acknowledgment of OECD as source and copyright owner is given. All requests for commercial use and translation rights should be submitted to rights@oecd.org. 


\section{TABLE OF CONTENTS}

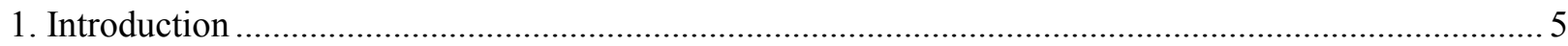

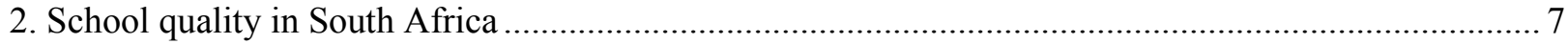

3. Data and sample

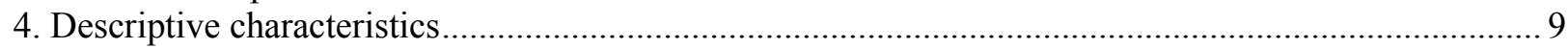

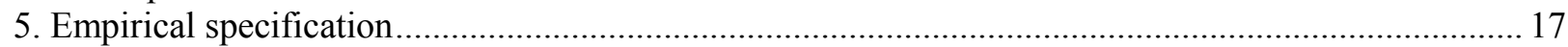

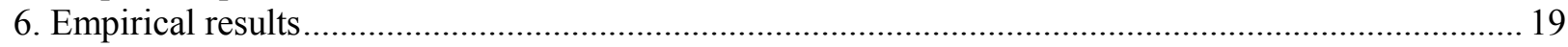

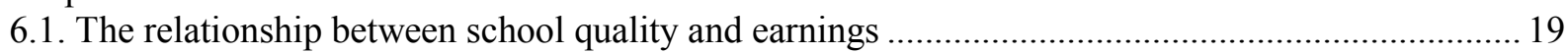

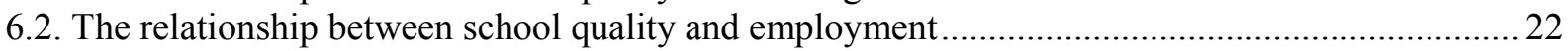

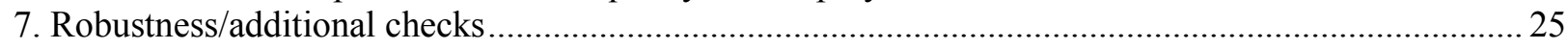

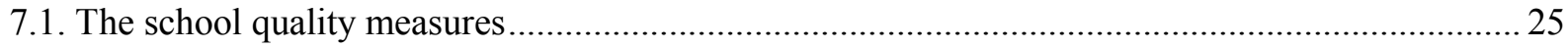

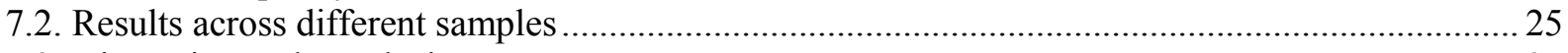

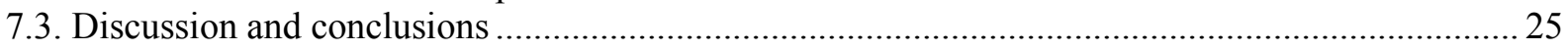

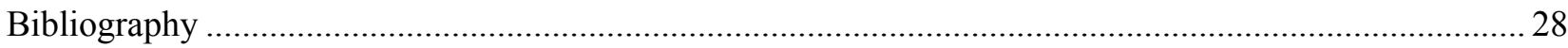

\section{Tables}

1. Sample characteristics by matric score category for the full sample, those who have never moved and

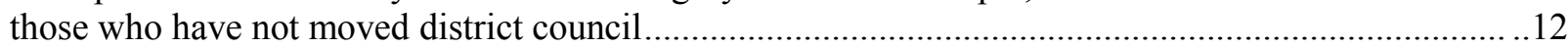

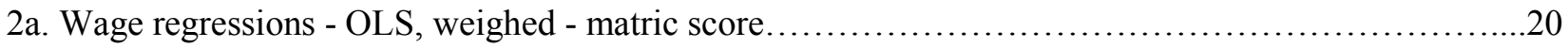

2b. Wage regressions - OLS, weighed - pupil/teacher ratios..................................... 21

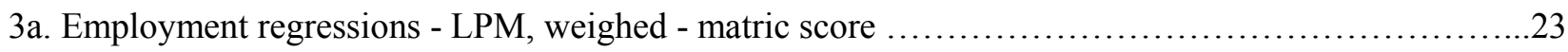

3b. Employment regressions - LPM, weighed - pupil/teacher ratio.................................24

\section{Figures}

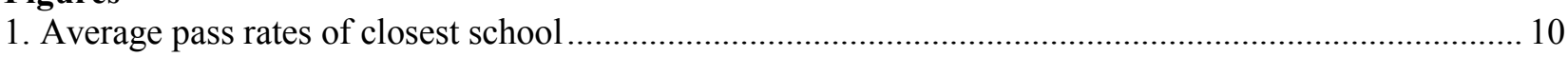

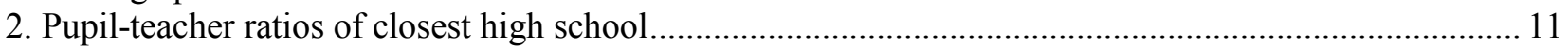

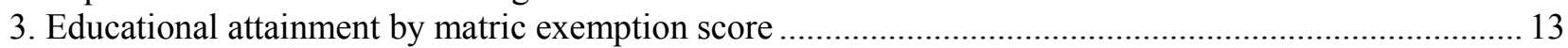

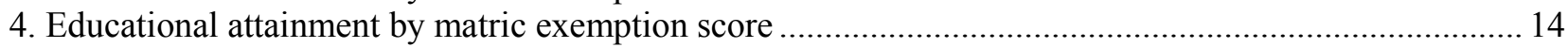

5. Share in each education category by matric exemption score ….......................................................... 15

6. Proportion of each education category employed by matric exemption score ...................................... 16

7. Log wages for each education category by matric exemption score …................................................ 17 
ECO/WKP(2013)13 
ECO/WKP(2013)13

\title{
EDUCATION QUALITY AND LABOUR MARKET OUTCOMES IN SOUTH AFRICA
}

\author{
By Nicola Branson and Murray Leibbrandt ${ }^{1}$
}

\section{Introduction}

The importance and impact of educational input on learner's life outcomes is of key policy interest. Over $17 \%$ of public expenditure in South Africa is allocated to education (UNESCO, 2011), yet educational outcomes remain poor and highly unequal. A dual education system exists in South Africa; the richest $25 \%$ of learners achieve acceptable outcomes on international and national tests, while the average outcomes of the majority are extremely poor (Spaull, 2012). Infrastructure, the number of teachers per student and teacher competency vary substantially between rich and poor schools. Therefore the question of what the impact would be of reducing these differences in educational input is of immediate importance.

Educational outcomes are fundamental in determining what opportunities are available to an individual after leaving school. Returns to education in the South African labour market are high for those completing secondary school and tertiary education (Keswell and Poswell, 2004). Yet South Africa bears the burden of a highly segregated and unequal education system inherited from the past with structural barriers that perpetuate the divide between rich and poor. Spatial divisions between the rich and the poor are one primary barrier. Most learners attend school in their immediate neighbourhood and the quality of schools and their success in the final matric exam, vary by the income of these neighbourhoods. As such the children of poor parents attend, for the most part, low-quality primary schools that feed dysfunctional high schools with high repetition and dropout rates and low and poor-quality matric results (Spaull, 2012; Branson et al., 2012; Chamberlain and van der Berg, 2002). Given the limited post school options available in South Africa (Gibbon, Muller and Nel, 2012), this limits learners' options for post secondary education and thus restricts them to low-level jobs. Children of the poor thus end up in low-quality jobs, are more likely to be unemployed and the cycle of poverty and inequality continues.

School quality can impact an individual's returns in the labour market in three distinct ways. First, school quality can affect the amount of education an individual attains. Case and Deaton (1999) find that decreasing the pupil/teacher ratio by 10 children improves average educational attainment by 0.6 years. Case and Yogo (1999), who find similar aggregate estimates, note that there are non-linearities in the relationship between educational attainment and pupil/teacher ratios, with effects much larger in environments where pupil/teacher ratios are high. Second, school quality, even controlling for education level, may affect an individuals' ability to find employment. The quality of schooling could affect an individual's quality of search, ability to maintain a job or, in the case of matriculants and those with tertiary, provide a signal to the market. In South Africa, a learner can complete matric with or without an exemption. An exemption makes the individual eligible to study in a tertiary institution. For matrics the distinction in type of matric pass can be used to signal quality while for those who go on to tertiary it is

1. Nicola Branson is a postdoctoral research fellow in the Southern Africa Labour and Development Research Unit (SALDRU) at the University of Cape Town. Murray Leibbrandt is Professor of Economics and Director of SALDRU at the University of Cape Town and the National Research Foundation Research Chair of Poverty and Inequality. E-mails: nicola.branson@gmail.com, murray.leibbrandt@uct.ac.za. The authors are grateful to Geoff Barnard and Fabrice Murtin for helpful comments and suggestions. This paper was commissioned by the OECD Economics Department in the context of the 2013 Economic Survey of South Africa. The views expressed in this study are those of the authors, and are not necessarily those of the OECD or of its member countries. 
likely to determine the type of qualification achieved. Lastly, school quality can impact earnings directly through its impact on the quality of the worker.

One of the criticisms of Mincerian type estimates of the returns to education levels in South Africa has been the absence of controls for measures of school quality. Hertz (2003) argues that omitted variable bias in standard OLS estimates results in severely upwardly biased estimates of the return to educational attainment when in fact part of the difference in educational attainment is attributable to school quality and other unobserved individual and household characteristics. One of our key interests in this paper is how sensitive the educational attainment estimates from a standard Mincerian regression are to the inclusion of school quality measures.

Estimates of the relationship between school quality and labour market outcomes in South Africa have been restricted by data limitations. Case and Yogo (1999) is the only paper on South Africa that directly controls for measures of school quality in regressions of labour market success as per Card and Krueger (1992) and Heckman et al. (1995). They find a significant effect of lowering the pupil/teacher ratio on the wages of males and the employment opportunities of females. They use the 1991 South African Census and the Education Atlas of 1991. Other papers address the school quality-labour market success topic indirectly. Moll (1996) infers a relationship between school quality and earnings by looking at shifts between age cohorts who experienced different education systems and hence quality of education. Moll (1998) and Burger and van der Berg (2011) focus on test outcomes that will be partly a function of ability and partly a function of school quality. Hertz (2003) controls for unobserved confounders, implicitly including school quality, using statistical methods like family fixed effects.

There are three primary reasons why estimating the relationship between school quality and labour market success is challenging empirically. First, it is well acknowledged that school choice and outcomes are endogenously determined. Parents with a stronger taste for education can move to neighbourhoods with better schools or lobby for better education within their child's current school and simultaneously provide the personal guidance and assistance for their child to make better progress at school. This parental taste for education is unmeasured. Case and Yogo (1999) use the residential and school choice limitations on Africans during apartheid to study the impact of school quality on a population where endogeneity is less likely to play a role. The second empirical difficulty arises as a result of measurement error in school quality and educational attainment. This can attenuate the estimates. Consensus in the US literature is that the measurement error and omitted variable bias are similar in size and hence cancel each other out (Hertz, 2003). However, this has not been investigated for estimates from developing countries (Hertz, 2003). Last, few datasets have information to match prime working-age adults with sufficient information about the conditions of their schooling, a fundamental data requirement for this work.

We use data from the National Income Dynamic Study (NIDS) to isolate a group of prime working-age African adults who would have completed their education before the end of apartheid. We map measures of school quality from the Schools Register of Needs and Department of Basic Education matric data on geographic proximity to complete our data package. This paper contributes in three ways to what is known about returns to education and school quality in South Africa. First, these estimates confirm what Case and Yogo (1999) have found using a different methodology and different data; namely, that there is an important relationship between school quality, employment and wages in South Africa. Second, our estimates are more recent and for a sample of prime-aged African males. Case and Yogo (1999) investigate the impact of school quality on cohorts of individuals between 25 and 35 in 1996, we investigate the impact on 32-59 year olds in 2008. Third, we include as a measure of school quality, matric scores, which have not yet been investigated in this context. Arguably, matric scores directly impact future life options and success in the labour market and reflect the combined effect of quality measures within the school. 
We find that the returns to educational attainment are robust to the inclusion of two school quality measures. African males with matric earn on average 1.5 times the wage of someone with primary and those with tertiary earn on average close to four times the primary-only wage. School quality is however found to have a direct positive effect on the earnings of African males. Using measures of quality from the respondents' closest school, we find that increasing the average matric score by $10 \%$, for example from 40 to $50 \%$, increases the earnings of a worker who attended that school by $8 \%$ on average. Workers with primary education are most sensitive to school quality. Similarly, decreasing the pupil/teacher ratio improves earnings significantly. We find less of a relationship between school quality and employment.

The rest of the paper is organised as follows. Section 2 provides a brief historical outline of the educational context in South Africa and how this history provides an empirical strategy to control, to a certain degree, for endogeneity in school choice. The data and sample used in the analysis are presented in Section 3 with sample characteristics illustrated in Section 4. Section 5 lays out the specification, with the analysis following in Section 6. Section 7 discusses some of the limitations of the empirical strategy and checks, where possible, the robustness of the results. Section 8 concludes.

\section{School quality in South Africa}

This section provides some context about education and education policy in South Africa to motivate the empirical strategy and the importance of the school quality variables used.

School quality is strongly related to socioeconomic status in South Africa. The majority $(75 \%)$ of learners attend dysfunctional schools and achieve well below international and national recommended standards, while the richest $25 \%$ of the population attend functional schools and achieve at the appropriate level (Spaull, 2012). This inequality in access to schools of quality originated from the severe limits placed on residential mobility and the unequal educational funding, support and management across different areas in the 'Bantustan' system. The apartheid government forced African families into homelands based on their language, areas characterised by limited employment prospects and poor resources, in particular in schools. The schooling system was divided along racial lines with 11 different administration systems responsible for the schooling of Africans (Case and Yogo, 1999). These administration systems were grouped into three categories- those provinces which the white government wanted ultimately to comprise SA, the Self-governing territories and the 'independent' homelands (Case and Deaton, 1999). The first two groups were centrally controlled by the Department of Education and Training (DET) and the Minister of National Education respectively. Although the 'independent' homelands had more control over their budgets, the Department of Foreign Affairs played a key role in determining the budget allocation for these governments. ${ }^{2}$

Some improvements have been made since the end of Apartheid in 1994, but inequalities in education remain starkly delineated along socioeconomic lines. All schools now fall under one department of basic education and racial funding differentials have been equalised. Schools are classified into quintiles based on the socioeconomic characteristics of their neighbourhood, with the poorest $20 \%$ of schools in quintile 1 and the richest $20 \%$ of schools in quintile 5 .

2. "This system generated marked discrepancies in educational funding per pupil across racial groups and place of residence. Taking Blacks in the DET schools as unity, funding levels for Whites, Asians, Coloureds, Blacks in SGTs, and Blacks in homelands were, respectively, 1.85, 1.61, 1.59, 0.74, and 0.67 (South African Institute of Race Relations, 1997). Given the very limited control that the Black population had over location and resource allocation, an unusually large fraction of the variation in school resources across districts was independent of the educational choices of Black parents and their children" (Case and Deaton, 1999, p. 1049). 
Yet the combination of private and public school funding still disadvantages poor schools. While non-personnel expenditure is allocated on a pro-poor basis with schools in the lower quintiles receiving a higher allocation per learner, personnel expenditure, the lion's share of aggregate expenditure, remains inequitably distributed. Personnel expenditure is allocated using a 'post-provisioning' formula related to the experience and qualifications of the teachers employed. Since better quality teachers gravitate towards higher quintile schools, poor schools receive on average less personnel expenditure than richer schools. In addition, quintile 1 and 2 schools are no-fee schools and are prohibited from charging school fees, while richer schools supplement their incomes with funds raised through school fees. These additional funds enable them to employ more teachers and improve the teaching environment and other school facilities. In this way the divide between rich and poor schools is perpetuated and continues the cycle of marked differences in educational outcomes across schools.

\section{Data and sample}

Three data sources are used in the analysis; the National Income Dynamics Study (NIDS), the School Register of Needs Survey (SRN) 2000 and school level matriculation results from 2000. NIDS is South Africa's first national longitudinal study and two waves of data, from 2008 and 2010, are currently available. NIDS is particularly suitable to this research question as it contains detailed schooling, labour market and socioeconomic information. In addition, NIDS collects information on where the individual currently lives, their place of residence in 1994 and where they were born. We use these variables to augment the data with school quality measures from the SRN and department of education matric scores. The SRN surveyed all schools in the country to gather information on schools' location, infrastructure and availability of resources (SRN report from DataFirst, 2000). The Department of Education matric score data include, at the level of the school, the number of learners who enrolled to write matric, the number who wrote and the number who passed with a senior certificate or with a senior certificate with exemption.

The sample is restricted to African individuals who are likely to have completed their education prior to the end of apartheid. As motivated in Section 2, analyses of this sample are less vulnerable to endogeneity of school choice bias. In addition, these respondents are prime working-age. If we assume that individuals complete their education at age 18, anyone older than 32 in wave $1(2008-1994+18)$ or 34 if first interviewed in $2010(2010-1994+18)$ is eligible to be included in our sample. The sample therefore contains individuals between the ages of 32 and 65 . We include both those first interviewed first in wave 1 or wave 2.

We investigate two school quality measures: pupil/teacher ratios and the percentage of students within the school who completed matric with an exemption that would allow them to go to university. Pupil/teacher ratios reflect educational resources available to the school, while matric results capture the complex link between factors that influence successful school outcomes. These include school management, teacher quality, infrastructure and socioeconomic disadvantage.

Ideally we would want a school quality measure that coincides with when the respondent completed their schooling. NIDS collects information on the school the respondent last attended in addition to the year they completed this education, but these questions are poorly answered for our sample of interest. ${ }^{3}$ As a result we use an alternative measure and present the results using the actual school attended in the robustness checks. The school quality measures used are characteristics of the high school closest to the respondent's household. Branson et al. (2012) find that over 70\% of South African learners in 2008 attend either their closest school or a school within $2 \mathrm{~km}$ of their closest school. It is therefore not unreasonable to

3. These questions have poor responses for two reasons; non-response on these questions is high and for those who responded, few could be correctly matched to the schools list (Branson, Lam and Zuze, 2012). 
assume that the closest high school presents a likely option for most respondents, especially given residential restrictions at the time.

The school quality measures are matched to individual NIDS respondents on geographic distance. The matric score data contained no geographical coordinate information and was therefore first matched to the SRN 2000 data on name and location. Once matched, secondary schools that were formerly allocated as 'African only' schools ${ }^{4}$ were selected to form a database of secondary schools. Using the geographic coordinates of NIDS households and the school, we match NIDS respondents to the closest school from the constructed secondary school database. Thus each respondent is assigned the pupil/teacher ratio and matric score of their closest 'African only' secondary school.

The data strategy used has three potential weaknesses. We list each and then explain how we tested for the sensitivity of estimated results to these weaknesses.

First, we use 2000 school quality measures from the closest secondary school when our sample was specifically chosen to have completed their education before the end of apartheid, thus there will be measurement error in the school quality variable. Those who left the schooling system at different times or who attended different schools may have experienced different levels of school quality. Unfortunately, 2000 were the earliest matric results we could obtain and a decision was made to match the pupil/teacher ratio to this year. However, it is not unreasonable to presume a high level of persistence in results within schools. Case and Yogo (1999) model the potential attenuation bias introduced by this type of timing error. Assuming that quality evolves in a random way (which they argue was characteristic of education decisions at the time) they estimate very small levels of bias relative to the quality effect (Case and Yogo, 1999).

The second concern is that we use the closest secondary school from the individual's current household as this is the household for which we have geographic coordinate information. This is not necessarily where the respondent lived when completing their education. NIDS has information on who has moved and where they were born and living in $1994.72 \%$ of individuals from our sample report that they have never moved, and of those who have moved, 55\% lived in the same district council as they did in 1994. We use this information to test the sensitivity of our results by restricting the sample to those who have never moved and those who have not moved district councils.

Last, it is possible that the quality measures capture something systematic about the area in which the school is located and do not reflect school quality per se. We control for this by including district council of birth fixed effects and parental education.

The next section presents descriptive characteristics of the data.

\section{Descriptive characteristics}

A learner can pass the national senior certificate with a pass, a conditional exemption pass or a complete exemption pass. An exemption senior certificate pass is required to study at a tertiary institution, with a conditional exemption pass subject to specific conditions and valid for a limited period of time (Government Notice 1272 and 1354). Figure 1 presents the distribution of the different matric score

4. Department of education and training (DET), Transkei, Bophuthatswana, Ciskei, Gazankulu, KaNgwane, KwaNdebele, KwaZulu, Lebowa, Qwaqwa and Venda. This means that House of Assembly (HOA), Delegates (HOD) and Representative (HOR), Transvaal education department (TED) and new education department schools were excluded. 
measures for the sample. The figure illustrates the low incidence of respondents for whom the closest high school achieved a matric pass rate above $50 \%$. This is especially true for senior certificate passes with exemption where the modal point is below $5 \%$.

Figure 1. Average pass rates of closest school

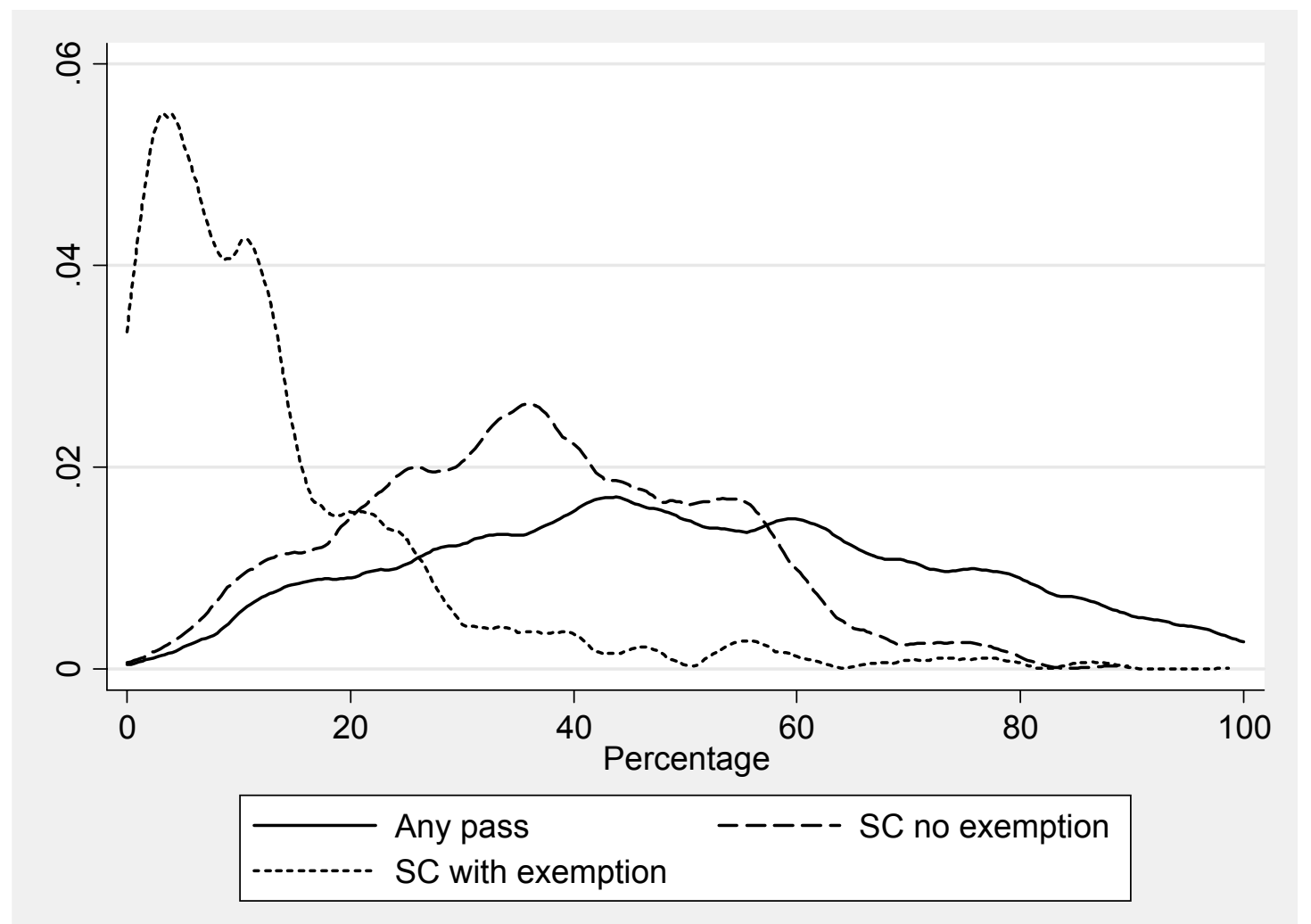

Note: The figure presents kernel densities of the 2000 pass rates of sample respondents' closest high school. The sample is restricted to those who have never moved. Three pass measures are used. Any pass includes senior certificate (SC) passes with or without an exemption. Exemption includes both complete and conditional exemptions. 
Figure 2. Pupil-teacher ratios of closest high school

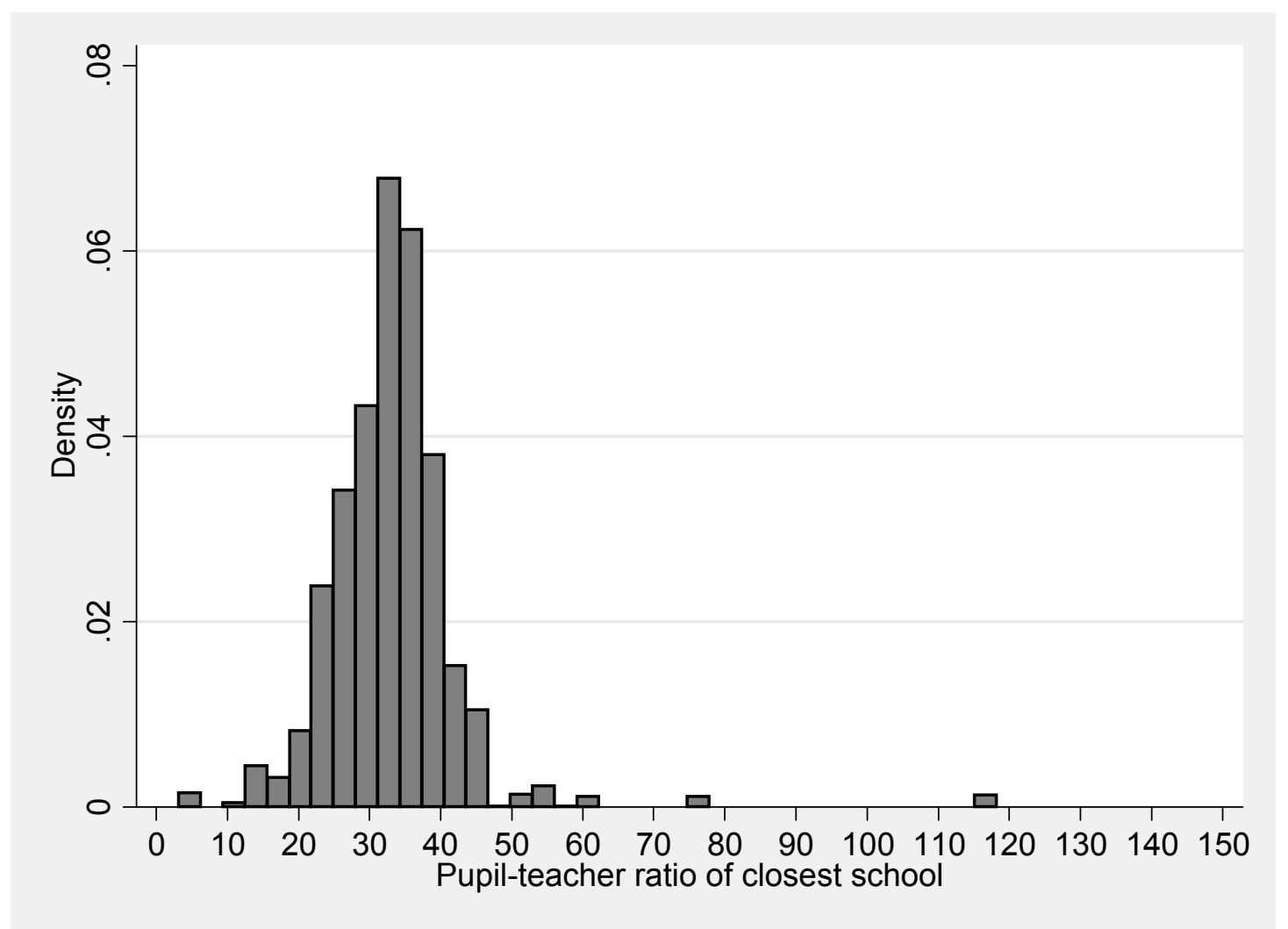

Note: The figure presents kernel densities of the ratio of learners to teachers in 2000 of sample respondents' closest high school. The sample is restricted to those who have never moved.

Figure 2 shows the distribution of pupil/teacher ratios from respondents' closest secondary schools. A half of respondents are assigned schools where the pupil/teacher ratio is between 28 and 36 . However, around $25 \%$ of respondents are assigned schools where each teacher is matched to over 36 learners, with the tail extending to well over 60 learners per teacher. 
Table 1. Sample characteristics by matric score category for the full sample, those who have never moved and those who have not moved district council

\begin{tabular}{|c|c|c|c|c|c|c|c|c|c|}
\hline & \multicolumn{3}{|c|}{ All } & \multicolumn{3}{|c|}{ Never moved } & \multicolumn{3}{|c|}{ Same district council } \\
\hline & Low $(<5.5)$ & $\begin{array}{c}\text { Medium } \\
(5.5-12.9) \\
\end{array}$ & $\begin{array}{c}\text { High (13- } \\
100)\end{array}$ & Low $(<5.5)$ & $\begin{array}{c}\text { Medium } \\
(5.5-12.9) \\
\end{array}$ & $\begin{array}{c}\text { High (13- } \\
100)\end{array}$ & Low $(<5.5)$ & $\begin{array}{c}\text { Medium } \\
(5.5-12.9) \\
\end{array}$ & $\begin{array}{c}\text { High (13- } \\
100)\end{array}$ \\
\hline Proportion & & & & 0.78 & 0.73 & 0.69 & 0.88 & 0.85 & 0.83 \\
\hline \multicolumn{10}{|l|}{ Individual characteristics: } \\
\hline Proportion male & 0.40 & 0.45 & 0.44 & 0.36 & 0.41 & 0.38 & 0.38 & 0.42 & 0.38 \\
\hline Age & 45.41 & 44.78 & 44.73 & 45.76 & 45.27 & 45.39 & 45.92 & 45.36 & 45.52 \\
\hline Mother's education & 2.54 & 2.46 & 2.70 & 2.30 & 2.43 & 2.60 & 2.42 & 2.35 & 2.58 \\
\hline Father's education & 2.31 & 2.34 & 2.55 & 2.19 & 2.09 & 2.41 & 2.23 & 2.10 & 2.39 \\
\hline \multicolumn{10}{|l|}{ Individual outcomes: } \\
\hline Years of education & 6.87 & 7.35 & 7.59 & 6.50 & 7.10 & 7.39 & 6.71 & 7.11 & 7.44 \\
\hline \multicolumn{10}{|l|}{ Proportion } \\
\hline Economically Active & 0.69 & 0.75 & 0.74 & 0.65 & 0.74 & 0.69 & 0.68 & 0.73 & 0.71 \\
\hline Employment rate & 0.73 & 0.73 & 0.75 & 0.71 & 0.71 & 0.72 & 0.73 & 0.71 & 0.73 \\
\hline Wage & 2335.31 & 2931.94 & 2828.11 & 2075.38 & 3001.32 & 2650.58 & 2229.69 & 2884.48 & 2692.13 \\
\hline \multicolumn{10}{|l|}{ School characteristics: } \\
\hline SC no exemption & 26.95 & 40.64 & 43.46 & 27.49 & 40.39 & 41.92 & 26.90 & 40.47 & 43.13 \\
\hline SC with exemption & 2.54 & 9.28 & 29.80 & 2.65 & 9.19 & 29.85 & 2.57 & 9.25 & 29.10 \\
\hline Pupil teacher ratio & 32.39 & 33.35 & 31.67 & 33.23 & 33.22 & 32.42 & 32.50 & 33.41 & 32.41 \\
\hline Distance to school & 2.69 & 3.35 & 3.00 & 2.88 & 3.15 & 2.82 & 2.72 & 3.14 & 2.76 \\
\hline Sample Size & 2089 & 1994 & 2077 & 1625 & 1455 & 1439 & 1832 & 1686 & 1725 \\
\hline
\end{tabular}

Note: The table presents mean characteristics and sample sizes for three samples of interest: the full African sample aged 32-64, a subsample who have never moved and a subsample who have not moved district council. The samples are further divided into respondent's whose closest school's matric exemption rate in 2000 was below 5.5\%, between 5.5 and 12.9 and $13+$ percent. All means are weighted using the NIDS post stratification weights.

Table 1 presents summary sample characteristics by matric score category for the full sample, individuals who have never moved and those who have not moved to another district council. Respondents are divided into categories based on whether their closest secondary school scored a senior certificate with exemption pass rate of less than $5.5 \%$, between 5.5 and $12.9 \%$ or $13 \%$ plus. The first row of the table shows that individuals grouped into the higher matric score areas are more likely to have moved. The difference between the highest and lowest score categories is statistically significant at the $10 \%$ significance level.

The next panel presents information on the respondent's characteristics and shows that respondents in the higher matric score areas are of similar average age and are equally likely to be male. As may be expected, parental education increases for individuals residing in higher score areas. One of the concerns is that better educated parents seek to live in areas with better quality schools or that this reflects differences in neighbourhood characteristics that determine both labour market outcomes and school quality measures. We control for parental education and district council of birth in the final regression specification.

The third panel presents average educational and labour market outcomes for each of the three score categories. As discussed in the introduction, school quality is likely to impact both the level of schooling an individual achieves and their labour market outcomes. The table shows that for each of the samples, education increases for higher score levels. Figure 3 presents this relationship, for those who have not moved, for the full matric score spectrum in addition to the relationship between years of education and the pupil-teacher ratio. The figure includes both a scatter of the mean educational attainment of respondents in our sample against our school quality measures and the overall trend from locally weighted least squares regressions. This nonparametric approach allows the data to describe the general patterns present in the data. We use a bandwidth of 0.8. The same method is used to produce Figure 4 through 6 . 
Figure 3. Educational attainment by matric exemption score

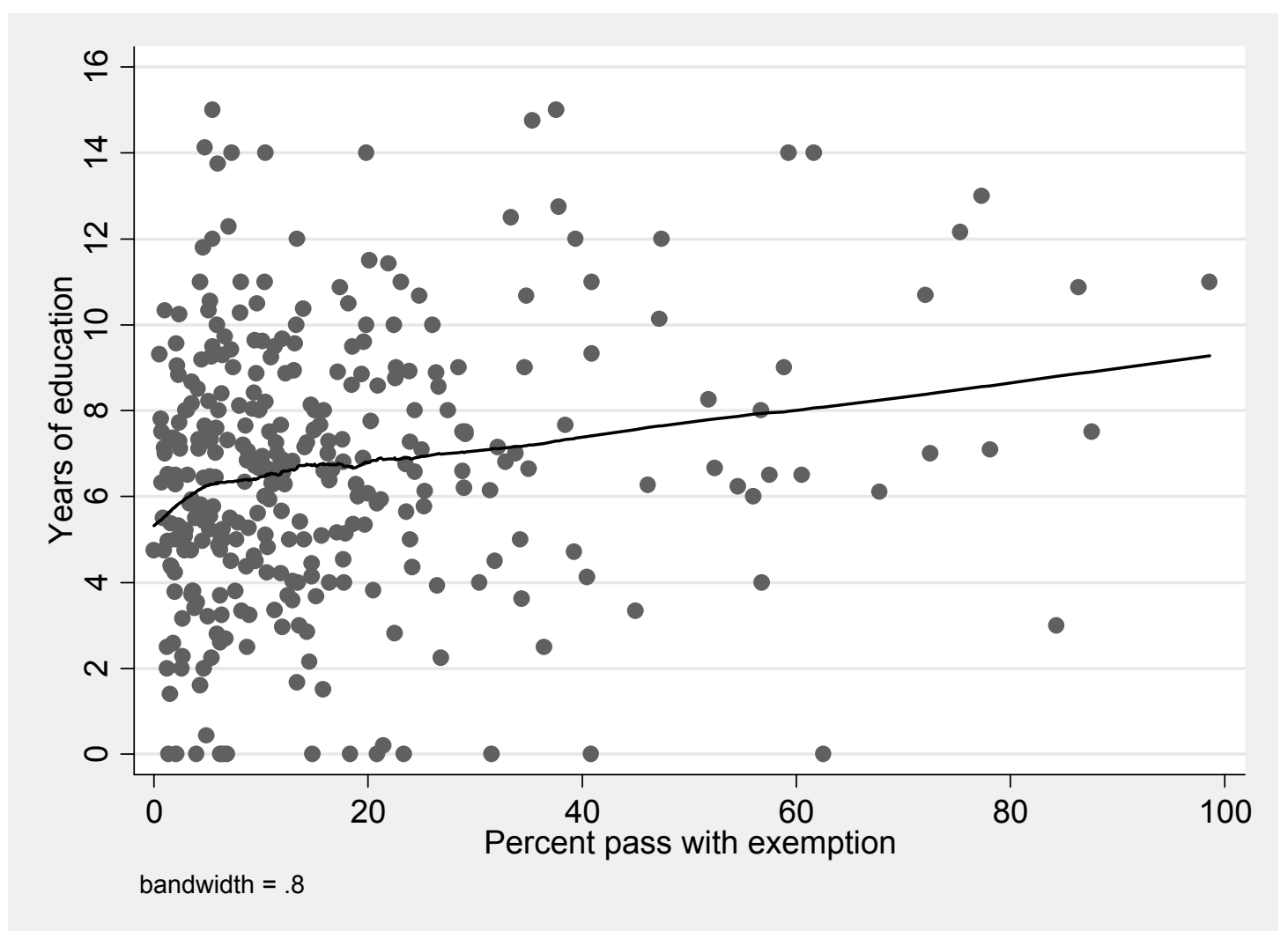

Note: The figure presents mean educational attainment by matric exemption pass rate of the closest school (the scatter) and a locally weighted regression line (smoothed using a 0.8 bandwidth). The sample is restricted to respondents who have never moved and all estimates are weighted using the NIDS post stratification weights. It may seem strange that the average educational attainment of those attending schools with close to $100 \%$ exemption rates is only 11 years or that there are points reflecting zero years of education but a positive matric exemption score. First, it is important to note that while this is the closest school to the individuals' household, it is not necessarily the school they attended or the year they attended the school. Second this disjunction is likely to reflect high dropout rates, especially in late secondary education. The matric exemption rate is calculated using the number of students who wrote matric as the denominator. Those who drop out before matric or choose not to write the exam are excluded. Finally, care should be taken in reading into the numbers at the upper extreme of the matric score continuum since sample sizes are extremely small.

The slope of the line in the left panel of Figure 3 is strongly positive and linear, increasing from an average of six years of education for respondents whose closest school has a $0 \%$ matric exemption pass rate to around nine years of education for respondents whose closest school scores close to $100 \%$. It may seem strange that the average educational attainment of those attending schools with close to $100 \%$ exemption rates is only 11 years ${ }^{5}$ or that the average education at a school with a positive pass rate is zero. There are two key reasons for these anomalies. First, the disjuncture between exemption rates and average educational attainment will reflect in part high dropout rates, especially in late secondary education. The matric exemption rate is calculated using the number of students who wrote matric as the denominator. Those who drop out before matric or choose not to write the exam are excluded. Second, while this is the closest school to the individuals' household, it is not necessarily the school they attended or the year they attended the school. Our identification strategy just assumes that this is a good proxy for the school the

5. About $30 \%$ of matriculants continue on to tertiary of between 1 and 5 years, therefore we would expect an average closer to 13 years. 
individual attended. ${ }^{6}$ The right hand panel of Figure 3, similarly show that respondents whose assigned schools had lower ratios of pupils to teachers attained more education. Note however, that reducing class sizes below 18 learners is not related to improved educational attainment.

Figure 4. Educational attainment by matric exemption score

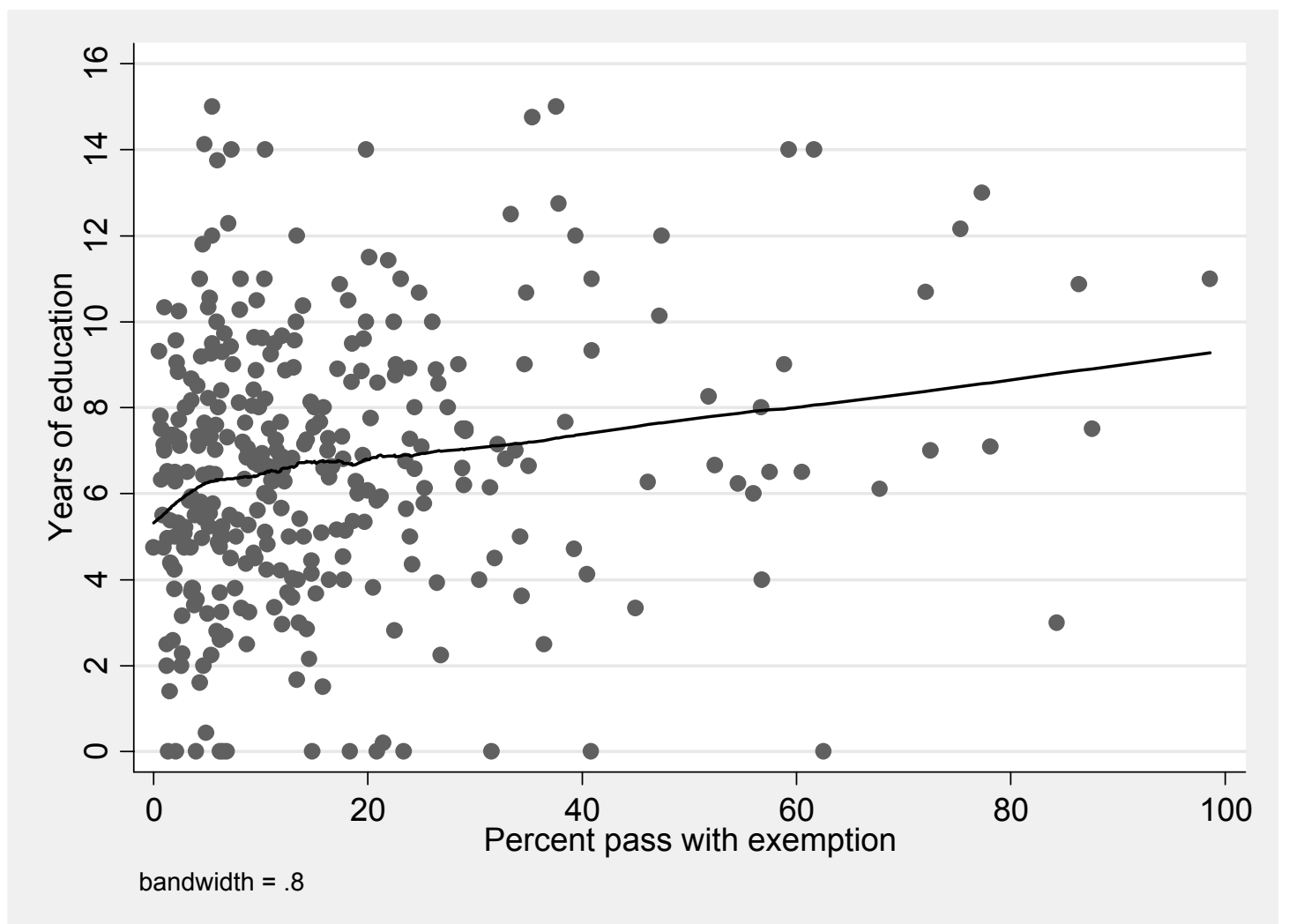

Note: The figure presents mean educational attainment by matric exemption pass rate of the closest school (the scatter) and a locally weighted regression line (smoothed using a 0.8 bandwidth). The sample is restricted to respondents who have never moved and all estimates are weighted using the NIDS post stratification weights. It may seem strange that the average educational attainment of those attending schools with close to $100 \%$ exemption rates is only 11 years or that there are points reflecting zero years of education but a positive matric exemption score. First, it is important to note that while this is the closest school to the individuals' household, it is not necessarily the school they attended or the year they attended the school. Second this disjunction is likely to reflect high dropout rates, especially in late secondary education. The matric exemption rate is calculated using the number of students who wrote matric as the denominator. Those who drop out before matric or choose not to write the exam are excluded. Finally, care should be taken in reading into the numbers at the upper extreme of the matric score continuum since sample sizes are extremely small.

Figure 4 shows the shift in the share of respondents in four educational category groups by the school quality measures. Respondents who completed 0-7 years are categorized as primary, 8-11 years as incomplete secondary, 12 years as matric and 13+ years as tertiary. We see a fall in the share of respondents with primary or no education and an increase in the shares of each of the other categories as the matric exemption score increases ${ }^{7}$. Note that while the proportion with matric appears fairly stable, the share with tertiary is increasing. Since matric is a prerequisite for tertiary, the share with matric is increasing too. The relationship between education category share and pupil-teacher ratio is non-linear.

6. A final potential reason for the disjunction between educational attainment and matric exemption score is that the samples at the upper extreme of the matric score continuum are extremely small.

7. There are very few students attending schools with exemption scores above $60 \%$. 
Increasing the ratio of pupils to teachers above 18 increases the share who attain only primary and decreases the share with matric and tertiary. The share with incomplete secondary is only affected once classes are increased above 35 learners to a teacher. For classes of 18 learners to a teacher or less, almost the exact opposite is evident. The share of primary decreases with an increase in the pupil-to-teacher ratio and the share of incomplete secondary and tertiary decreases. The share with matric does however increase. Care should be taken in placing too much emphasis on these initial points as sample sizes are small for low pupil-to-teacher ratios. It does however highlight that the relationship between educational attainment and pupil-teacher ratio is not necessarily linear. This reaffirms Case and Yogo's (1999) findings.

Figure 5. Share in each education category by matric exemption score

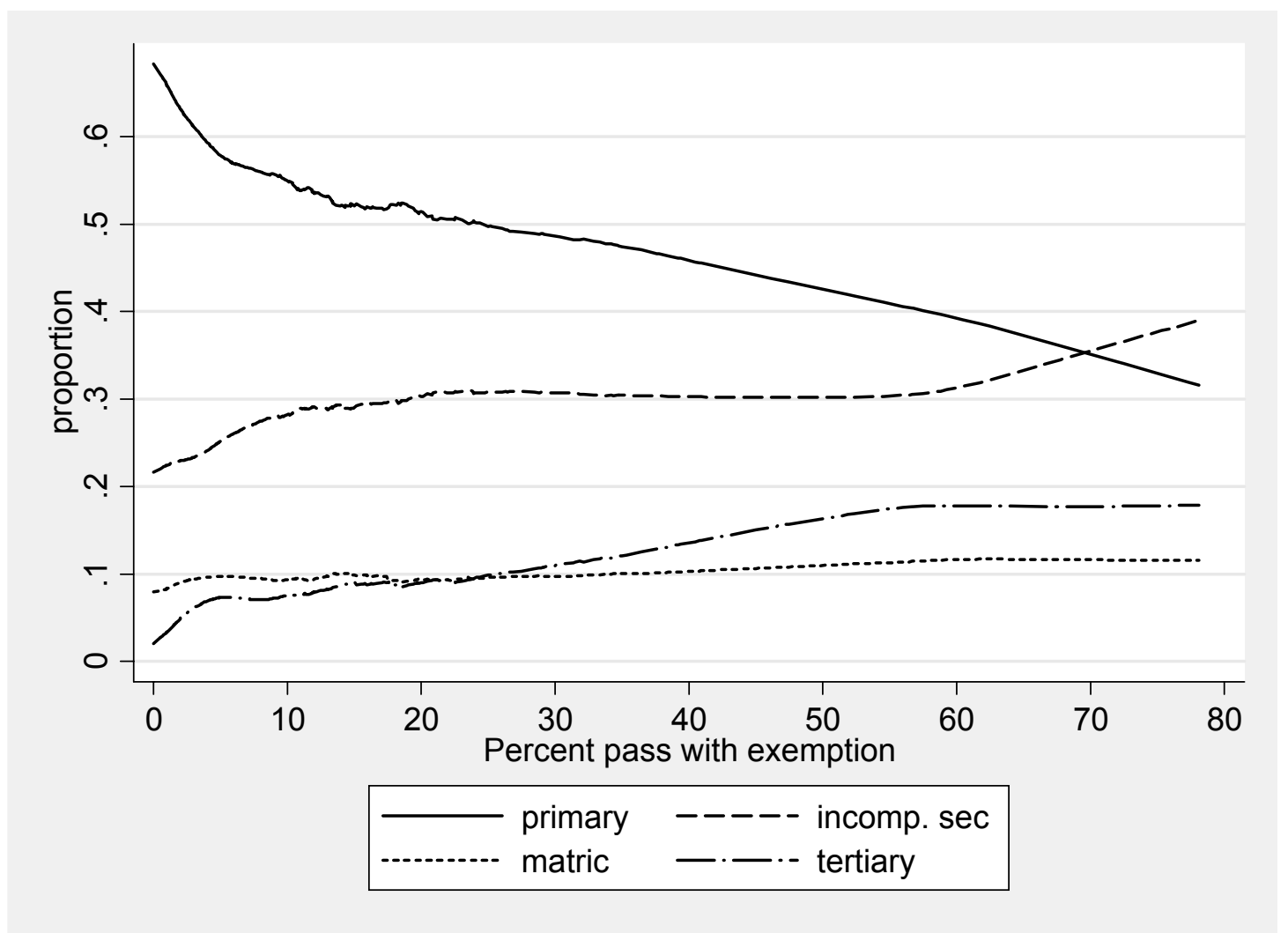

Note: The figure presents the proportion with primary or less, incomplete secondary, matric and tertiary by the matric score of the respondent's closest high school. The lines are smoothed using locally weighted least squares regression with a bandwidth of 0.8 . The sample is restricted to respondents who have not moved and estimates are weighted using the NIDS post stratification sample weight. Labour market outcomes are examined by score level in the next three lines of Table 1. Labour market outcomes improve between the lowest and the middle score category, but the progress is less clear between the middle and upper categories. Given that educational attainment increases systematically by score category, this is unexpected. In Figures 5 and 6 we therefore present the proportion employed and average log wages by score, in addition to pupil-teacher ratios, for each of the education categories. The relationship between employment and score differs across education groups.

Labour market outcomes are examined by score level in the next three lines of Table 1. Labour market outcomes improve between the lowest and the middle score category, but the progress is less clear between the middle and upper categories. Given that educational attainment increases systematically by score category, this is unexpected. In Figures 5 and 6 we therefore present the proportion employed and average $\log$ wages by score, in addition to pupil-teacher ratios, for each of the education categories. The relationship between employment and score differs across education groups. 
The relationship between employment and matric score is positive for those with primary and matric. For example, around $60 \%$ of matrics whose closest high school scored around $10 \%$ are employed, while over $85 \%$ of matric whose closest high school scored around $60 \%$ matric exemption rate are employed. The relationship is less systematic for those with incomplete secondary, although it is positive between 10 and $20 \%$, where most of the density lies.

The relationship between wages and the matric score is also distinct by education category. For primary and tertiary, wages increase, on the whole, in the matric score while for incomplete secondary and matric they are extremely linear (except at the end points).

Figure 6. Proportion of each education category employed by matric exemption score

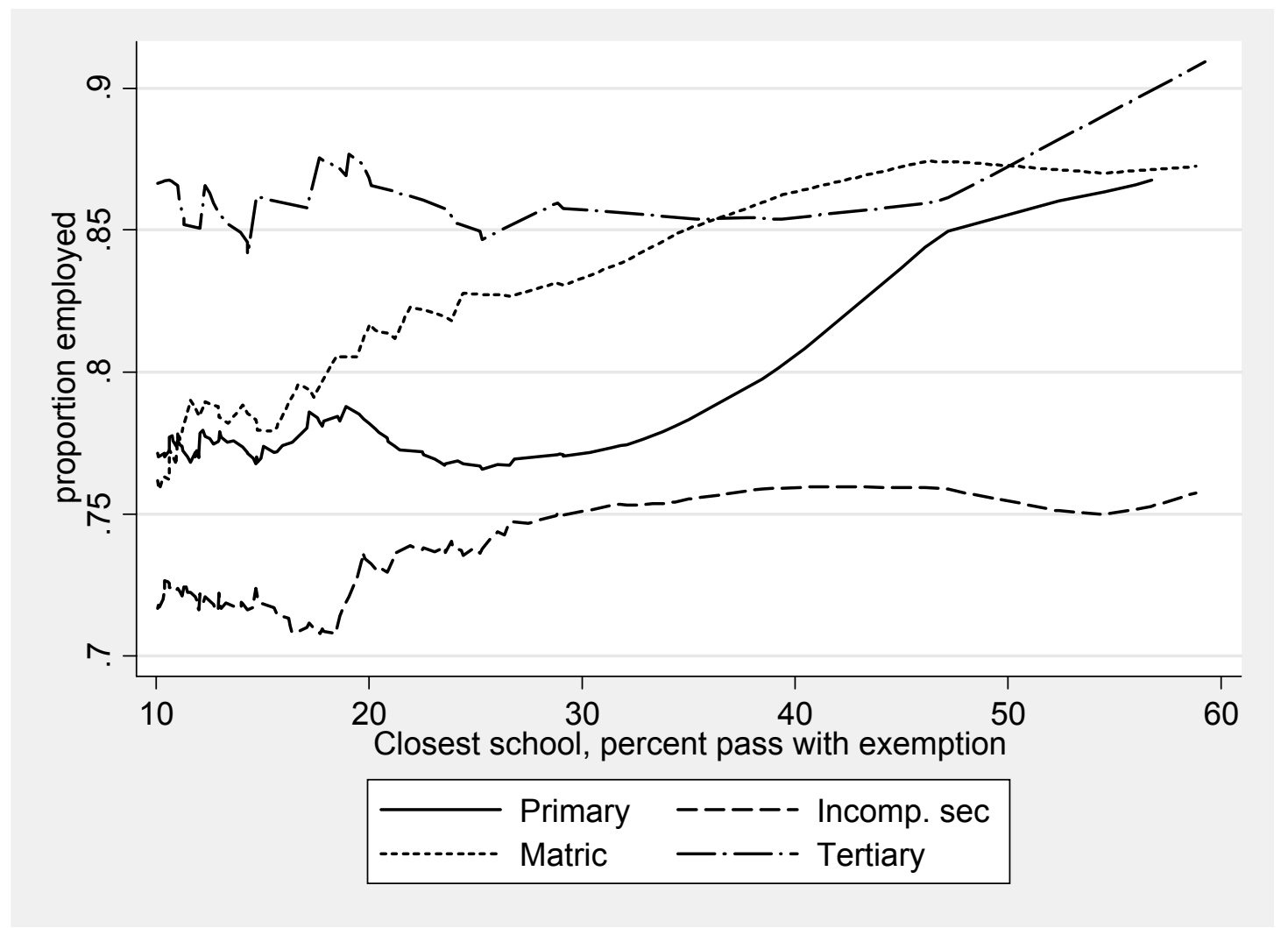

Note: The figure presents the proportion within each education category by the matric score of the respondent's closest high school. The lines are smoothed using locally weighted least squares regression with a bandwidth of 0.8 . The sample is restricted to male respondents who have not moved and estimates are weighted using the NIDS post stratification sample weight. 
Figure 7. Log wages for each education category by matric exemption score

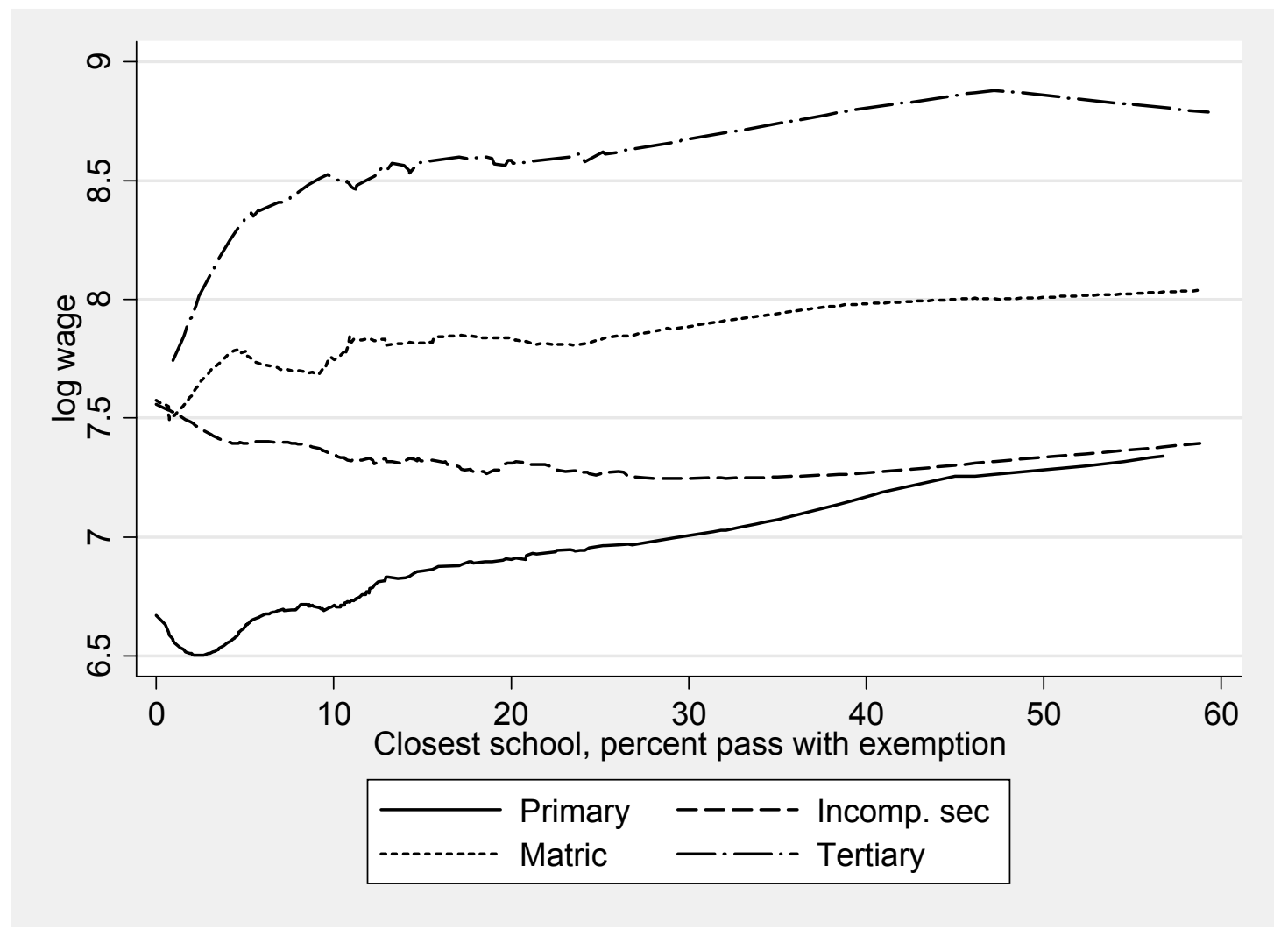

Note: The figure presents the average log wage within each education category by the matric score of the respondent's closest high school. The lines are smoothed using locally weighted least squares regression with a bandwidth of 0.8 . The sample is restricted to male respondents who have not moved and estimates are weighted using the NIDS post stratification sample weight.

These summary tables and figures illustrate that there appears to be a relationship between school quality and educational attainment and labour market outcomes. Therefore, in the next section, we proceed to examine this relationship in a multivariate framework.

\section{Empirical specification}

Card and Krueger (1999) summarise four empirical strategies used in the returns to education literature to incorporate the impact of school quality. Type 1 specifications simply include the school quality measure in the standard Mincerian equation and hence assume that school quality has the same impact on returns, regardless of education level. Type 2 specifications acknowledge that the assumption of constant returns across education level is unlikely to be realistic by including interactions between the school quality measure and educational level. The third type of specification controls for unobserved characteristics of the area where the individual was educated as well as characteristics of their area of employment. This two step process first estimates a region-cohort specific return to education and then relates this to a region-cohort specific school quality measure (Card and Krueger, 1999). The final type of specification calculates the reduced form relationship between earnings and school quality, excluding education level from the model. In this way it incorporates both the direct and indirect effect of school quality on earnings.

Our choice of specification is motivated by our primary question of interest; namely, are the estimates of the returns to educational attainment as measured in the standard OLS Mincerian specification severely 
upward biased by the absence of controls for school quality? As such we present estimates from type 1 and 2 models so that we can see directly what happens to the Mincerian returns when school quality is added. We do however go some way towards controlling for district socioeconomic variation during childhood through the inclusion of district of birth fixed effects and parental education.

We therefore run two main specifications:

Specification 1: Assumes school quality has the same impact on employment and earnings, regardless of education level

$$
Y_{i}=\alpha+\beta_{1} \text { incomsec }_{i}+\beta_{2} \text { matric }_{i}+\beta_{3} \text { tertiary }_{i}+\gamma_{1} S Q_{i s}+X_{i}^{\prime} \delta+\varepsilon_{i}
$$

Specification 2: Allows the impact of school quality to differ across different levels of education

$$
\begin{gathered}
Y_{i}=\alpha+\beta_{1} \text { incomsec }_{i}+\beta_{2} \text { matric }_{i}+\beta_{3} \text { tertiary }_{i}+\gamma_{1} S Q_{i s}+\gamma_{2} S Q_{i s} * \text { incomsec }_{i}+\gamma_{3} \text { SQ }_{i s} * \text { matric }_{i} \\
+\gamma_{4} S_{i s} * \text { tertiary }_{i}+X_{i}^{\prime} \delta+\varepsilon_{i}
\end{gathered}
$$

where $Y_{i}$ is either an indicator of employment or the $\log$ of monthly wages, $\beta_{1}$ through $\beta_{3}$ are the coefficients on indicators of whether the respondent has incomplete secondary, matric or tertiary, with primary or no schooling as the reference category ${ }^{8} . S Q_{i s}$ is a measure of the quality of respondent $i$ 's closest high school $s, X_{i}$ is a matrix of control variables (specified below) and $\varepsilon_{i}$ is an individual error term. Specification 2 includes interactions between the school quality measure and the education categories and in this way allows the slope of the school quality - earnings (or employment) relationship to differ across different education levels. Two school quality measures are investigated; the matric exemptions pass rate and the log of the pupil-teacher ratio. The sample is restricted to African males 32-59 years old.

Control variables $\left(X_{i}\right)$ are included additively in the regression tables. The first two columns for each set of regressions include only a quadratic in age. The remaining three columns add indicators for marital status, parental education and urban residence. Note, we would ideally want to control for differences in the mean characteristics of the area where the individual went to school to be assured that the school quality measures are not picking up differences in incomes arising from these differences (e.g average educational level of adults, good health care, parents with jobs, etc.). Controlling for parental education goes some way towards dealing with this. In addition, the final two columns include a full set of district council of birth indicators. In this way, unmeasured characteristics of the district council are absorbed into this fixed effect.

8. It may seem strange that we include respondents with no schooling when our interest is the effect school quality measures have on earnings premiums. However, given that we use a proxy measure for quality, i.e. the quality of the respondent's nearest school, we choose to include them. The quality of schooling in an individuals neighbourhood may affect the choice of whether to attend school or not. Also because our measure is completed years of schooling, other respondents may have attended but never completed any education. Excluding those with zero education from the regression analysis reduces the matric score coefficient in the final model (without interaction) from 0.008 to 0.006 but the final results remain significant. Similarly, the pupil-teacher ratio coefficient declines from 0.025 to 0.023 and remains significant. 
ECO/WKP(2013)13

\section{Empirical results}

\subsection{The relationship between school quality and earnings}

Table $2 \mathrm{a}$ and $\mathrm{b}$ presents the earnings equation regression results using matric exemption score and pupil/teacher ratio as the school quality measure respectively. In each table, the first five columns present results for the full sample, the next five columns for a sample of respondents who have not moved district council and the last five columns for a sample of respondents who have never moved. Column 1 presents a specification where the results are comparable to those in Branson and Leibbrandt (2013). The specification includes educational category indicators, with primary or no schooling as the reference, and a quadratic control for age.

Columns 1 in Table $2 \mathrm{a}$ and $\mathrm{b}$ show that the coefficients on incomplete secondary, matric and tertiary accord well with similar estimates from the national dataset in 2008 estimated in Branson and Leibbrandt (2013). In fact, it is evident by comparing columns 1 through 5, that these coefficients are only slightly lower when quality is controlled for. Incomplete secondary increases earnings by over half, matric increases earning by 1.5 times and tertiary by close to 4 times the earnings of those with primary.

There is a significant relationship between the rate of matric exemption of a worker's school and his wages, even after controlling for education level. This relationship is not a function of individual characteristics, parental education or other unobserved characteristics of the district council in which the respondent was born. The size of the coefficient actually increases with the addition of controls and the district council of birth fixed effects. In column 4 of Table $2 \mathrm{a}$, a $1 \%$ increase in the matric exemption score of the closest high school is associated with a 0.8 increase in wages. Put differently, increasing the school's matric exemption rate by $10 \%$ is associated with an $8 \%$ increase in wages. The score coefficient is sensitive to the inclusion of controls and increases in size and significance between columns 2 and 5 .

Column 5 of Table $2 \mathrm{a}$ includes the interaction between the matric exemption score and education level to allow for the impact of quality to differ by education level. In order to assess the association between school quality and wages for incomplete secondary, matric and tertiary education levels, the coefficient from the matric score variable $\left(\gamma_{1}\right)$ must be added to the coefficient on the interaction term $\left(\gamma_{2}, \gamma_{3}, \gamma_{4}\right.$ for incomplete secondary, matric and tertiary respectively). The F-tests presented at the bottom of the table test for the joint significance of these coefficients.

The matric score coefficient increases substantially between columns 4 and 5. This coefficient represents the association between the school's matric score and wages for those with primary education. Increasing the matric exemption rate by $10 \%$ is associated with a $13 \%$ increase in wages among those with primary. The education level - matric score interaction coefficients are negative for the incomplete secondary, matric and tertiary interactions, signalling that the size of the association between school quality and wages for these levels of education is smaller than for those with primary; the estimated association for those with incomplete secondary, matric and tertiary is $0.004,0$ and 0.01 respectively. The F-tests also show that the relationship is not statistically significant for the incomplete secondary and matric groups. Only the F-test for the tertiary group is statistically significant. Increasing the matric exemption rate by $10 \%$ is associated with a $10 \%$ increase in wages among those with tertiary. 
Table 2a. Wage regressions - OLS, weighed - matric score

\begin{tabular}{|c|c|c|c|c|c|c|c|c|c|c|c|c|c|c|c|}
\hline & $\begin{array}{l}(1) \\
\text { all } \\
\end{array}$ & $\begin{array}{l}(2) \\
\text { all } \\
\end{array}$ & $\begin{array}{l}\text { (3) } \\
\text { all }\end{array}$ & $\begin{array}{l}\text { (4) } \\
\text { all }\end{array}$ & $\begin{array}{l}(5) \\
\text { all } \\
\end{array}$ & $\begin{array}{c}\text { (6) } \\
\text { samedc }\end{array}$ & $\begin{array}{c}(7) \\
\text { samedc }\end{array}$ & $\begin{array}{c}\text { (8) } \\
\text { samedc }\end{array}$ & $\begin{array}{c}\text { (9) } \\
\text { samedc }\end{array}$ & $\begin{array}{c}(10) \\
\text { samedc }\end{array}$ & $\begin{array}{c}\text { (11) } \\
\text { nevermove } \\
\end{array}$ & $\begin{array}{c}\text { (12) } \\
\text { nevermove }\end{array}$ & $\begin{array}{c}\text { (13) } \\
\text { nevermove }\end{array}$ & $\begin{array}{c}\text { (14) } \\
\text { nevermove }\end{array}$ & $\begin{array}{c}\text { (15) } \\
\text { nevermove }\end{array}$ \\
\hline Reference (Primary): & & & & & & & & & & & & & & & \\
\hline Incomplete Secondary & $\begin{array}{c}0.506 * * * \\
(0.091)\end{array}$ & $\begin{array}{c}0.505^{* * *} \\
(0.091)\end{array}$ & $\begin{array}{c}0.415^{* * *} \\
(0.090)\end{array}$ & $\begin{array}{c}0.423 * * * \\
(0.078)\end{array}$ & $\begin{array}{c}0.498^{* * * *} \\
(0.103)\end{array}$ & $\begin{array}{c}0.523 * * * \\
(0.105)\end{array}$ & $\begin{array}{c}0.519^{* * *} \\
(0.104)\end{array}$ & $\begin{array}{c}0.437 * * * \\
(0.105)\end{array}$ & $\begin{array}{c}0.453^{* * *} \\
(0.092)\end{array}$ & $\begin{array}{c}0.492^{* * *} \\
(0.124)\end{array}$ & $\begin{array}{c}0.648^{* * * *} \\
(0.110)\end{array}$ & $\begin{array}{c}0.647 * * * \\
(0.109)\end{array}$ & $\begin{array}{c}0.527^{* * *} \\
(0.117)\end{array}$ & $\begin{array}{c}0.514^{* * *} \\
(0.110)\end{array}$ & $\begin{array}{c}0.570 * * * \\
(0.142)\end{array}$ \\
\hline Matric & $\begin{array}{c}0.934^{* * *} \\
(0.108)\end{array}$ & $\begin{array}{c}0.938^{* * *} \\
(0.107)\end{array}$ & $\begin{array}{c}0.836 * * * \\
(0.107)\end{array}$ & $\begin{array}{c}0.823 * * * \\
(0.094)\end{array}$ & $\begin{array}{c}0.925^{* * *} \\
(0.116)\end{array}$ & $\begin{array}{c}1.074 * * * \\
(0.113)\end{array}$ & $\begin{array}{c}1.081^{* * *} \\
(0.114)\end{array}$ & $\begin{array}{c}0.934^{* * *} \\
(0.121)\end{array}$ & $\begin{array}{c}0.910^{* * *} \\
(0.108)\end{array}$ & $\begin{array}{c}0.968^{* * *} \\
(0.131)\end{array}$ & $\begin{array}{c}1.255^{* * * *} \\
(0.123)\end{array}$ & $\begin{array}{c}1.260^{* * * *} \\
(0.123)\end{array}$ & $\begin{array}{c}1.078 * * * \\
(0.133)\end{array}$ & $\begin{array}{c}1.056 * * * \\
(0.125)\end{array}$ & $\begin{array}{c}1.087 * * * \\
(0.156)\end{array}$ \\
\hline Tertiary & $\begin{array}{c}1.762^{* * *} \\
(0.176)\end{array}$ & $\begin{array}{c}1.749 * * * \\
(0.178)\end{array}$ & $\begin{array}{c}1.606 * * * \\
(0.175)\end{array}$ & $\begin{array}{c}1.596 * * * \\
(0.112)\end{array}$ & $\begin{array}{c}1.618^{* * *} \\
(0.138)\end{array}$ & $\begin{array}{c}1.851^{* * *} \\
(0.212)\end{array}$ & $\begin{array}{c}1.835 * * * \\
(0.212)\end{array}$ & $\begin{array}{c}1.639^{* * *} \\
(0.212)\end{array}$ & $\begin{array}{c}1.549^{* * *} \\
(0.134)\end{array}$ & $\begin{array}{c}1.436 * * * \\
(0.157)\end{array}$ & $\begin{array}{c}2.078 * * * \\
(0.219)\end{array}$ & $\begin{array}{c}2.057^{* * *} \\
(0.226)\end{array}$ & $\begin{array}{c}1.822^{* * *} \\
(0.225)\end{array}$ & $\begin{array}{c}1.688^{* * *} \\
(0.153)\end{array}$ & $\begin{array}{c}1.595 * * * \\
(0.178)\end{array}$ \\
\hline Matric score - closest high school & & $\begin{array}{c}0.004 \\
(0.004)\end{array}$ & $\begin{array}{l}0.006^{*} \\
(0.003)\end{array}$ & $\begin{array}{c}0.008^{* * *} \\
(0.003)\end{array}$ & $\begin{array}{l}0.013^{* *} \\
(0.005)\end{array}$ & & $\begin{array}{c}0.004 \\
(0.004)\end{array}$ & $\begin{array}{l}0.006^{*} \\
(0.003)\end{array}$ & $\begin{array}{c}0.009 * * * \\
(0.003)\end{array}$ & $\begin{array}{l}0.010^{*} \\
(0.006)\end{array}$ & & $\begin{array}{c}0.004 \\
(0.004)\end{array}$ & $\begin{array}{l}0.006^{*} \\
(0.003)\end{array}$ & $\begin{array}{c}0.006^{* * *} \\
(0.002)\end{array}$ & $\begin{array}{c}0.008 \\
(0.006)\end{array}$ \\
\hline Incomplete Secondary x matric score & & & & & $\begin{array}{l}-0.009 \\
(0.006)\end{array}$ & & & & & $\begin{array}{l}-0.005 \\
(0.007)\end{array}$ & & & & & $\begin{array}{l}-0.007 \\
(0.008)\end{array}$ \\
\hline Matric $\mathrm{x}$ matric score & & & & & $\begin{array}{c}-0.013^{*} \\
(0.007)\end{array}$ & & & & & $\begin{array}{l}-0.009 \\
(0.008)\end{array}$ & & & & & $\begin{array}{l}-0.005 \\
(0.008)\end{array}$ \\
\hline Tertiary $\mathrm{x}$ matric score & & & & & $\begin{array}{l}-0.003 \\
(0.008)\end{array}$ & & & & & $\begin{array}{c}0.009 \\
(0.008)\end{array}$ & & & & & $\begin{array}{c}0.006 \\
(0.009)\end{array}$ \\
\hline Age & $\begin{array}{c}0.135 * * * \\
(0.044)\end{array}$ & $\begin{array}{c}0.138^{* * *} \\
(0.043)\end{array}$ & $\begin{array}{l}0.065 * \\
(0.039)\end{array}$ & $\begin{array}{l}0.059 * \\
(0.035)\end{array}$ & $\begin{array}{l}0.062^{*} \\
(0.035)\end{array}$ & $\begin{array}{c}0.159 * * * \\
(0.051)\end{array}$ & $\begin{array}{c}0.159 * * * \\
(0.051)\end{array}$ & $\begin{array}{l}0.077^{*} \\
(0.047)\end{array}$ & $\begin{array}{c}0.047 \\
(0.044)\end{array}$ & $\begin{array}{c}0.046 \\
(0.044)\end{array}$ & $\begin{array}{c}0.159 * * * \\
(0.055)\end{array}$ & $\begin{array}{c}0.157 * * * \\
(0.055)\end{array}$ & $\begin{array}{c}0.076 \\
(0.056)\end{array}$ & $\begin{array}{c}0.069 \\
(0.055)\end{array}$ & $\begin{array}{c}0.068 \\
(0.056)\end{array}$ \\
\hline Age squared & $\begin{array}{c}-0.001^{* * * *} \\
(0.000)\end{array}$ & $\begin{array}{c}-0.001^{* * *} \\
(0.000)\end{array}$ & $\begin{array}{l}-0.001^{*} \\
(0.000)\end{array}$ & $\begin{array}{l}-0.001^{*} \\
(0.000)\end{array}$ & $\begin{array}{c}-0.001^{*} \\
(0.000)\end{array}$ & $\begin{array}{c}-0.002^{* * * *} \\
(0.001)\end{array}$ & $\begin{array}{c}-0.002^{* * * *} \\
(0.001)\end{array}$ & $\begin{array}{l}-0.001^{*} \\
(0.000)\end{array}$ & $\begin{array}{c}-0.001 \\
(0.000)\end{array}$ & $\begin{array}{l}-0.001 \\
(0.000)\end{array}$ & $\begin{array}{c}-0.002^{* * *} \\
(0.001)\end{array}$ & $\begin{array}{c}-0.002^{* * *} \\
(0.001)\end{array}$ & $\begin{array}{c}-0.001 \\
(0.001)\end{array}$ & $\begin{array}{c}-0.001 \\
(0.001)\end{array}$ & $\begin{array}{c}-0.001 \\
(0.001)\end{array}$ \\
\hline $\begin{array}{l}\text { Martial status/parental edu/urban } \\
\text { controls? }\end{array}$ & No & No & Yes & Yes & Yes & No & No & Yes & Yes & Yes & No & No & Yes & Yes & Yes \\
\hline District council controls ? & No & No & No & Yes & Yes & No & No & No & Yes & Yes & No & No & No & Yes & Yes \\
\hline Constant & $\begin{array}{c}3.822^{* * *} \\
(0.992)\end{array}$ & $\begin{array}{c}3.721 * * * \\
(0.968)\end{array}$ & $\begin{array}{c}5.813^{* * *} \\
(0.891)\end{array}$ & $\begin{array}{c}5.756 * * * \\
(0.795)\end{array}$ & $\begin{array}{c}5.716^{* * *} \\
(0.795)\end{array}$ & $\begin{array}{c}3.175^{* * *} \\
(1.161)\end{array}$ & $\begin{array}{c}3.159 * * \\
(1.149)\end{array}$ & $\begin{array}{c}5.447^{* * * *} \\
(1.069)\end{array}$ & $\begin{array}{c}5.906 * * * \\
(1.010)\end{array}$ & $\begin{array}{c}6.045^{* * *} \\
(1.021)\end{array}$ & $\begin{array}{l}2.955^{* *} \\
(1.269)\end{array}$ & $\begin{array}{l}2.970^{* *} \\
(1.267)\end{array}$ & $\begin{array}{c}5.235 * * * \\
(1.292)\end{array}$ & $\begin{array}{c}5.360^{* * *} \\
(1.252)\end{array}$ & $\begin{array}{c}5.410 * * \\
(1.268)\end{array}$ \\
\hline Observations & 1,527 & 1,527 & 1,523 & 1,523 & 1,523 & 1,247 & 1,247 & 1,247 & 1,247 & 1,247 & 1,000 & 1,000 & 1,000 & 1,000 & 1,000 \\
\hline R-squared & 0.251 & 0.253 & 0.325 & 0.397 & 0.399 & 0.257 & 0.259 & 0.341 & 0.425 & 0.428 & 0.309 & 0.313 & 0.378 & 0.434 & 0.436 \\
\hline F-test:tert & & & & & 3.453 & & & & & 10.79 & & & & & 4.984 \\
\hline Prob $>$ F:tert & & & & & 0.0640 & & & & & 0.00114 & & & & & 0.0263 \\
\hline F-test:matric & & & & & 0.00531 & & & & & 0.0120 & & & & & 0.527 \\
\hline Prob $>$ F:matric & & & & & 0.942 & & & & & 0.913 & & & & & 0.468 \\
\hline F-test:incomsec & & & & & 0.694 & & & & & 1.081 & & & & & 0.0322 \\
\hline Prob > F:incs & & & & & 0.406 & & & & & 0.299 & & & & & 0.858 \\
\hline
\end{tabular}

${ }^{* * *} p<0.01,{ }^{* *} p<0.05,{ }^{*} p<0.1$ 
ECO/WKP(2013)13

Table 2b. Wage regressions - OLS, weighed - pupil teacher ratios

\begin{tabular}{|c|c|c|c|c|c|c|c|c|c|c|c|c|c|c|c|}
\hline & $\begin{array}{l}(2) \\
\text { all } \\
\end{array}$ & $\begin{array}{l}(3) \\
\text { all } \\
\end{array}$ & $\begin{array}{l}(4) \\
\text { all } \\
\end{array}$ & $\begin{array}{l}(5) \\
\text { all } \\
\end{array}$ & $\begin{array}{l}\text { (6) } \\
\text { all } \\
\end{array}$ & $\begin{array}{c}(8) \\
\text { samedc }\end{array}$ & $\begin{array}{c}(9) \\
\text { samedc } \\
\text { s. }\end{array}$ & $\begin{array}{c}(10) \\
\text { samedc }\end{array}$ & $\begin{array}{c}(11) \\
\text { samedc }\end{array}$ & $\begin{array}{c}(12) \\
\text { samedc }\end{array}$ & $\begin{array}{c}\begin{array}{c}(14) \\
\text { nevermove }\end{array} \\
\text { e }\end{array}$ & $\begin{array}{c}(15) \\
\text { nevermove }\end{array}$ & $\begin{array}{c}\begin{array}{c}(16) \\
\text { nevermove }\end{array}\end{array}$ & $\begin{array}{c}\begin{array}{c}(17) \\
\text { nevermove }\end{array} \\
\end{array}$ & $\begin{array}{c}\begin{array}{c}(18) \\
\text { nevermove }\end{array} \\
\text { e }\end{array}$ \\
\hline $\begin{array}{l}\text { Reference (Primary): } \\
\text { Incomplete Secondary }\end{array}$ & $\begin{array}{c}0.512 * * \\
(0.087)\end{array}$ & $\begin{array}{c}0.430 * * * \\
(0.086)\end{array}$ & $\begin{array}{c}0.432 * * * \\
(0.076)\end{array}$ & $\begin{array}{c}0.436 * * * \\
(0.075)\end{array}$ & $\begin{array}{l}0.273 \\
(0.204)\end{array}$ & $\begin{array}{c}0.529 * * * \\
(0.100)\end{array}$ & $\begin{array}{c}0.458^{* * *} \\
(0.101)\end{array}$ & $\begin{array}{c}0.473 * * * \\
(0.089)\end{array}$ & $\begin{array}{c}0.479 * * * \\
(0.088)\end{array}$ & $\begin{array}{l}0.318 \\
(0.248)\end{array}$ & $\begin{array}{c}0.652^{* * *} \\
(0.108)\end{array}$ & $\begin{array}{c}0.539 * * * \\
(0.116)\end{array}$ & $\begin{array}{c}0.524 * * * \\
(0.107)\end{array}$ & $\begin{array}{c}0.531^{* * *} \\
(0.105)\end{array}$ & $\begin{array}{l}0.496^{*} \\
(0.257)\end{array}$ \\
\hline Matric & $\begin{array}{c}0.910^{* * *} \\
(0.112)\end{array}$ & $\begin{array}{c}0.827^{* * *} \\
(0.108)\end{array}$ & $\begin{array}{c}0.809^{* * * *} \\
(0.096)\end{array}$ & $\begin{array}{c}0.805^{* * * *} \\
(0.096)\end{array}$ & $\begin{array}{c}0.319 \\
(0.245)\end{array}$ & $\begin{array}{c}1.051^{* * *} \\
(0.120)\end{array}$ & $\begin{array}{c}0.927^{* * *} * \\
(0.119)\end{array}$ & $\begin{array}{c}0.905^{* * *} \\
(0.108)\end{array}$ & $\begin{array}{c}0.904^{* * *} \\
(0.108)\end{array}$ & $\begin{array}{l}0.598^{* *} \\
(0.272)\end{array}$ & $\begin{array}{c}1.241^{* * *} \\
(0.127)\end{array}$ & $\begin{array}{c}1.069^{* * *} \\
(0.133)\end{array}$ & $\begin{array}{c}1.049^{* * *} \\
(0.127)\end{array}$ & $\begin{array}{c}1.046^{* * *} \\
(0.127)\end{array}$ & $\begin{array}{l}0.690^{*} \\
(0.364)\end{array}$ \\
\hline Tertiary & $\begin{array}{c}1.753 * * * \\
(0.182)\end{array}$ & $\begin{array}{c}1.639^{* * *} \\
(0.174)\end{array}$ & $\begin{array}{c}1.622^{* * *} \\
(0.111)\end{array}$ & $\begin{array}{c}1.620^{* * *} \\
(0.111)\end{array}$ & $\begin{array}{c}1.320^{* * * *} \\
(0.287)\end{array}$ & $\begin{array}{c}1.848 * * * \\
(0.218)\end{array}$ & $\begin{array}{c}1.687^{* * * *} \\
(0.210)\end{array}$ & $\begin{array}{c}1.598^{* * * *} \\
(0.136)\end{array}$ & $\begin{array}{c}1.601^{* * * *} \\
(0.135)\end{array}$ & $\begin{array}{c}1.396 * * * \\
(0.362)\end{array}$ & $\begin{array}{c}2.076 * * * \\
(0.224)\end{array}$ & $\begin{array}{c}1.861^{* * * *} \\
(0.221)\end{array}$ & $\begin{array}{c}1.724^{* * * *} \\
(0.154)\end{array}$ & $\begin{array}{c}1.725 * * * \\
(0.153)\end{array}$ & $\begin{array}{c}1.590^{* * *} \\
(0.407)\end{array}$ \\
\hline Pupil/teacher ratio & $\begin{array}{l}-0.013 * \\
(0.008)\end{array}$ & $\begin{array}{l}-0.010 \\
(0.006)\end{array}$ & $\begin{array}{c}-0.011^{* *} \\
(0.005)\end{array}$ & $\begin{array}{c}-0.025^{* * *} \\
(0.008)\end{array}$ & $\begin{array}{l}-0.015^{* *} \\
(0.006)\end{array}$ & $\begin{array}{l}-0.011^{*} \\
(0.009)\end{array}$ & $\begin{array}{l}-0.011 \\
(0.007)\end{array}$ & $\begin{array}{l}-0.011^{* *} \\
(0.005)\end{array}$ & $\begin{array}{l}-0.027 * * * \\
(0.008)\end{array}$ & $\begin{array}{l}-0.014^{* *} \\
(0.006)\end{array}$ & $\begin{array}{l}-0.007 \\
(0.007)\end{array}$ & $\begin{array}{l}-0.006 \\
(0.005)\end{array}$ & $\begin{array}{l}-0.008^{*} \\
(0.005)\end{array}$ & $\begin{array}{l}-0.022^{* *} \\
(0.010)\end{array}$ & $\begin{array}{l}-0.010 \\
(0.007)\end{array}$ \\
\hline Pupil/teacher ratio2 & & & & $\begin{array}{c}0.0002^{* * * *} \\
(0.000)\end{array}$ & & & & & $\begin{array}{c}0.0002^{* * *} \\
(0.000)\end{array}$ & & & & & $\begin{array}{c}0.0002^{* *} \\
(0.000)\end{array}$ & \\
\hline Incomplete Secondary x matric score & & & & & $\begin{array}{l}0.005 \\
(0.006)\end{array}$ & & & & & $\begin{array}{l}0.005 \\
(0.008)\end{array}$ & & & & & $\begin{array}{l}0.001 \\
(0.008)\end{array}$ \\
\hline Matric $x$ matric score & & & & & $0.016^{* *}$ & & & & & 0.010 & & & & & 0.012 \\
\hline Tertiary $\mathrm{x}$ matric score & & & & & $\begin{array}{c}0.010 \\
(0.009)\end{array}$ & & & & & $\begin{array}{c}0.006 \\
(0.010)\end{array}$ & & & & & $\begin{array}{c}0.004 \\
(0.011)\end{array}$ \\
\hline Age & $\begin{array}{c}0.137 * * * \\
(0.044)\end{array}$ & $\begin{array}{l}0.064 \\
(0.039)\end{array}$ & $\begin{array}{l}0.057 \\
(0.035)\end{array}$ & $\begin{array}{l}0.057 \\
(0.035)\end{array}$ & $\begin{array}{l}0.056 \\
(0.035)\end{array}$ & $\begin{array}{c}0.163 * * * \\
(0.051)\end{array}$ & $\begin{array}{l}0.081^{*} \\
(0.047)\end{array}$ & $\begin{array}{l}0.050 \\
(0.044)\end{array}$ & $\begin{array}{l}0.050 \\
(0.044)\end{array}$ & $\begin{array}{l}0.050 \\
(0.044)\end{array}$ & $\begin{array}{c}0.160 * * * \\
(0.055)\end{array}$ & $\begin{array}{c}0.079 \\
(0.055)\end{array}$ & $\begin{array}{l}0.072 \\
(0.055)\end{array}$ & $\begin{array}{l}0.072 \\
(0.055)\end{array}$ & $\begin{array}{l}0.073 \\
(0.055)\end{array}$ \\
\hline Age squared & $\begin{array}{c}-0.001^{* * *} \\
(0.000)\end{array}$ & $\begin{array}{l}-0.001^{*} \\
(0.000)\end{array}$ & $\begin{array}{l}-0.001^{*} \\
(0.000)\end{array}$ & $\begin{array}{l}-0.001^{*} \\
(0.000)\end{array}$ & $\begin{array}{l}-0.001^{*} \\
(0.000)\end{array}$ & $\begin{array}{c}-0.002 * * * \\
(0.001)\end{array}$ & $\begin{array}{c}-0.001^{*} \\
(0.001)\end{array}$ & $\begin{array}{c}-0.001 \\
(0.000)\end{array}$ & $\begin{array}{l}-0.001 \\
(0.000)\end{array}$ & $\begin{array}{l}-0.001 \\
(0.000)\end{array}$ & $\begin{array}{c}-0.002^{* * *} \\
(0.001)\end{array}$ & $\begin{array}{c}-0.001 \\
(0.001)\end{array}$ & $\begin{array}{l}-0.001 \\
(0.001)\end{array}$ & $\begin{array}{l}-0.001 \\
(0.001)\end{array}$ & $\begin{array}{l}-0.001 \\
(0.001)\end{array}$ \\
\hline Martial status/parental edu/urban controls? & No & Yes & Yes & Yes & Yes & Yes & Yes & Yes & Yes & Yes & Yes & Yes & Yes & Yes & Yes \\
\hline $\begin{array}{l}\text { District council controls? } \\
\text { ? }\end{array}$ & No & No & Yes & Yes & Yes & Yes & Yes & Yes & Yes & Yes & Yes & Yes & Yes & Yes & Yes \\
\hline Constant & $\begin{array}{c}4.213^{* * *} \\
(1.025)\end{array}$ & $\begin{array}{c}6.240^{* * *} \\
(0.935)\end{array}$ & $\begin{array}{c}6.224^{* * *} \\
(0.818)\end{array}$ & $\begin{array}{c}6.327 * * * \\
(0.834)\end{array}$ & $\begin{array}{c}6.546^{* * *} \\
(0.827)\end{array}$ & $\begin{array}{c}3.588^{* * *} \\
(1.195)\end{array}$ & $\begin{array}{c}5.779^{* * *} \\
(1.092)\end{array}$ & $\begin{array}{c}6.294^{* * *} \\
(1.020)\end{array}$ & $\begin{array}{c}6.416 * * * \\
(1.030)\end{array}$ & $\begin{array}{c}6.472^{* * *} \\
(1.018)\end{array}$ & $\begin{array}{l}3.159 * * \\
(1.305)\end{array}$ & $\begin{array}{c}5.422 * * * \\
(1.314)\end{array}$ & $\begin{array}{c}5.618^{* * *} \\
(1.265)\end{array}$ & $\begin{array}{c}5.749 * * * \\
(1.270)\end{array}$ & $\begin{array}{c}5.811^{* * *} \\
(1.272)\end{array}$ \\
\hline Observations & 1,527 & 1,523 & 1,523 & 1,523 & 1,523 & 1,247 & 1,247 & 1,247 & 1,247 & 1,247 & 1,000 & 1,000 & 1,000 & 1,000 & 1,000 \\
\hline $\begin{array}{l}\text { R-squared } \\
\text { F-test:tert }\end{array}$ & 0.261 & 0.327 & 0.396 & 0.398 & 0.398 & 0.269 & 0.344 & 0.424 & 0.426 & 0.424 & 0.312 & 0.375 & 0.432 & 0.434 & 0.433 \\
\hline $\begin{array}{l}\text { F-test:tert } \\
\text { Prob > F:tert }\end{array}$ & & & & & $\begin{array}{l}0.528 \\
0.468\end{array}$ & & & & & $\begin{array}{l}0.656 \\
0.419\end{array}$ & & & & & $\begin{array}{l}0.321 \\
0.571\end{array}$ \\
\hline F-test:matric & & & & & 0.0196 & & & & & 0.435 & & & & & 0.0247 \\
\hline Prob > F:matric & & & & & 0.889 & & & & & 0.510 & & & & & 0.875 \\
\hline F-test:incomsec & & & & & 3.014 & & & & & 2.201 & & & & & 1.667 \\
\hline Prob $>$ F:incs & & & & & 0.0835 & & & & & 0.139 & & & & & 0.198 \\
\hline
\end{tabular}


Shifting to the second and third panel of results in columns 6-10 and 11-15 in Table 2a shows some interesting differences in the returns to educational attainment among those who have not moved district council and those who have never moved, but little difference in size or significance of the school quality measure. The returns to education increase for each education category when estimated on the sample that has not moved district council and increase even further when the sample is restricted to those who have never moved. Focusing on the matric score coefficient, the differences are more subdued. The only real substantive difference is that the largest quality effect is for the tertiary group, once matric score/education category interactions are taken into account. In fact, in the group that has never moved, the tertiary group is the only education category whose overall coefficient is significantly affected by school quality (F-test $\mathrm{p}$-value is 0.02).

In Table $2 b$ we examine these relationships using the pupil/teacher ratio as the quality measure instead of matric exemption score. A similar story is evident. In particular, the education indicator coefficients are of a similar size and fairly robust when measured across the different specifications. Then, school quality appears predominantly to impact those with primary schooling. Indeed, once the interaction effects are included, only those with primary education are impacted by the quality measure. A one pupil reduction in the pupil/teacher ratio results in a $1 \%$ increase in earnings.

\subsection{The relationship between school quality and employment}

There is less evidence of a relationship between school quality and employment than was seen between school quality and wages. Table $3 \mathrm{a}$ and $\mathrm{b}$ present linear probability models for employment using matric score and pupil/teacher ratios to reflect school quality respectively. As was found for the wage regressions, the size and significance of the coefficients on the educational categories are similar to national data analysis. Only tertiary is found to have a significant effect on employment. The inclusion of the quality measure does not impact the education coefficients substantially.

School quality appears to play less of a direct role in determining employment than is does in determining wages. The matric exemption score coefficient is small and insignificant in all regressions. The pupil/teacher ratio coefficients are small and insignificant in all but the specification including interaction effects. Here we find a small and weakly significant effect. Reducing the number of learners under the responsibility of one teacher by 10 learners improves the employment odds by 0.03 units.

Increasing the matric score by $10 \%$ is associated with increases in wages of between $8 \%$ and $13 \%$, with those with primary most strongly affected. Estimates of the returns to education level remain robust to the inclusion of our measures of school quality. Matric and tertiary increase an individual's wages substantially, and tertiary improves the odds of employment as well. It is therefore clear that while school quality is likely to impact labour market outcomes indirectly through the level of education that an individual achieves, it also has a direct impact on wages. 
Table 3a. Employment regressions - LPM, weighted - matric score

\begin{tabular}{|c|c|c|c|c|c|c|c|c|c|c|c|c|c|c|c|}
\hline & $\begin{array}{l}\text { (1) } \\
\text { all }\end{array}$ & $\begin{array}{l}\text { (2) } \\
\text { all }\end{array}$ & $\begin{array}{l}\text { (3) } \\
\text { all }\end{array}$ & $\begin{array}{l}\text { (4) } \\
\text { all }\end{array}$ & $\begin{array}{l}\text { (5) } \\
\text { all }\end{array}$ & $\begin{array}{c}\text { (6) } \\
\text { samedc }\end{array}$ & $\begin{array}{c}\text { (7) } \\
\text { samedc }\end{array}$ & $\begin{array}{c}(8) \\
\text { samedc }\end{array}$ & $\begin{array}{c}\text { (9) } \\
\text { samedc }\end{array}$ & $\begin{array}{c}(10) \\
\text { samedc }\end{array}$ & $\begin{array}{c}\text { (11) } \\
\text { nevermove }\end{array}$ & $\begin{array}{c}\text { (12) } \\
\text { nevermove }\end{array}$ & $\begin{array}{c}\text { (13) } \\
\text { nevermove }\end{array}$ & $\begin{array}{c}\text { (14) } \\
\text { nevermove }\end{array}$ & $\begin{array}{c}\text { (15) } \\
\text { nevermove }\end{array}$ \\
\hline Reference (Primary): & & & & & & & & & & & & & & & \\
\hline Incomplete Secondary & $\begin{array}{l}-0.035 \\
(0.038)\end{array}$ & $\begin{array}{l}-0.035 \\
(0.038)\end{array}$ & $\begin{array}{l}-0.051 \\
(0.037)\end{array}$ & $\begin{array}{l}-0.050 \\
(0.036)\end{array}$ & $\begin{array}{l}-0.036 \\
(0.040)\end{array}$ & $\begin{array}{l}-0.050 \\
(0.040)\end{array}$ & $\begin{array}{l}-0.051 \\
(0.040)\end{array}$ & $\begin{array}{l}-0.067^{*} \\
(0.038)\end{array}$ & $\begin{array}{l}-0.069^{*} \\
(0.037)\end{array}$ & $\begin{array}{l}-0.053 \\
(0.042)\end{array}$ & $\begin{array}{l}-0.030 \\
(0.047)\end{array}$ & $\begin{array}{l}-0.031 \\
(0.047)\end{array}$ & $\begin{array}{l}-0.053 \\
(0.046)\end{array}$ & $\begin{array}{l}-0.058 \\
(0.044)\end{array}$ & $\begin{array}{l}-0.028 \\
(0.053)\end{array}$ \\
\hline Matric & $\begin{array}{c}0.063 \\
(0.046)\end{array}$ & $\begin{array}{c}0.062 \\
(0.046)\end{array}$ & $\begin{array}{c}0.039 \\
(0.045)\end{array}$ & $\begin{array}{c}0.048 \\
(0.045)\end{array}$ & $\begin{array}{c}0.054 \\
(0.054)\end{array}$ & $\begin{array}{l}0.088^{*} \\
(0.048)\end{array}$ & $\begin{array}{l}0.086^{*} \\
(0.048)\end{array}$ & $\begin{array}{c}0.058 \\
(0.050)\end{array}$ & $\begin{array}{c}0.076 \\
(0.048)\end{array}$ & $\begin{array}{c}0.086 \\
(0.052)\end{array}$ & $\begin{array}{c}0.092 \\
(0.061)\end{array}$ & $\begin{array}{c}0.091 \\
(0.061)\end{array}$ & $\begin{array}{c}0.059 \\
(0.061)\end{array}$ & $\begin{array}{c}0.080 \\
(0.060)\end{array}$ & $\begin{array}{c}0.106 \\
(0.065)\end{array}$ \\
\hline Tertiary & $\begin{array}{c}0.162^{* * *} \\
(0.033)\end{array}$ & $\begin{array}{c}0.158^{* * *} \\
(0.032)\end{array}$ & $\begin{array}{c}0.138^{* * *} \\
(0.041)\end{array}$ & $\begin{array}{c}0.146^{* * *} \\
(0.043)\end{array}$ & $\begin{array}{c}0.158^{* * *} \\
(0.050)\end{array}$ & $\begin{array}{c}0.173 * * * \\
(0.038)\end{array}$ & $\begin{array}{c}0.172^{* * *} \\
(0.038)\end{array}$ & $\begin{array}{c}0.133^{* * *} \\
(0.043)\end{array}$ & $\begin{array}{c}0.153^{* * *} \\
(0.045)\end{array}$ & $\begin{array}{c}0.172^{* * *} \\
(0.051)\end{array}$ & $\begin{array}{c}0.190^{* * *} \\
(0.047)\end{array}$ & $\begin{array}{c}0.184^{* * *} \\
(0.047)\end{array}$ & $\begin{array}{c}0.143^{* * *} \\
(0.050)\end{array}$ & $\begin{array}{c}0.180^{* * *} \\
(0.057)\end{array}$ & $\begin{array}{c}0.208^{* * *} \\
(0.062)\end{array}$ \\
\hline Matric score - closest high school & & $\begin{array}{c}0.001 \\
(0.001)\end{array}$ & $\begin{array}{c}0.001 \\
(0.001)\end{array}$ & $\begin{array}{c}0.001 \\
(0.001)\end{array}$ & $\begin{array}{c}0.001 \\
(0.001)\end{array}$ & & $\begin{array}{c}0.000 \\
(0.001)\end{array}$ & $\begin{array}{c}0.000 \\
(0.001)\end{array}$ & $\begin{array}{l}-0.000 \\
(0.002)\end{array}$ & $\begin{array}{c}0.001 \\
(0.002)\end{array}$ & & $\begin{array}{c}0.001 \\
(0.001)\end{array}$ & $\begin{array}{c}0.001 \\
(0.001)\end{array}$ & $\begin{array}{l}-0.000 \\
(0.001)\end{array}$ & $\begin{array}{c}0.002 \\
(0.002)\end{array}$ \\
\hline Incomplete Secondary $\mathrm{x}$ matric score & & & & & $\begin{array}{l}-0.002 \\
(0.003)\end{array}$ & & & & & $\begin{array}{l}-0.002 \\
(0.003)\end{array}$ & & & & & $\begin{array}{l}-0.004 \\
(0.003)\end{array}$ \\
\hline Matric $x$ matric score & & & & & $\begin{array}{l}-0.001 \\
(0.003)\end{array}$ & & & & & $\begin{array}{l}-0.001 \\
(0.003)\end{array}$ & & & & & $\begin{array}{l}-0.004 \\
(0.003)\end{array}$ \\
\hline Tertiary $\mathrm{x}$ matric score & & & & & $\begin{array}{l}-0.001 \\
(0.003)\end{array}$ & & & & & $\begin{array}{l}-0.002 \\
(0.003)\end{array}$ & & & & & $\begin{array}{l}-0.003 \\
(0.003)\end{array}$ \\
\hline Age & $\begin{array}{l}-0.007 \\
(0.015)\end{array}$ & $\begin{array}{l}-0.007 \\
(0.015)\end{array}$ & $\begin{array}{l}-0.023 \\
(0.015)\end{array}$ & $\begin{array}{l}-0.025 * \\
(0.014)\end{array}$ & $\begin{array}{l}-0.024^{*} \\
(0.014)\end{array}$ & $\begin{array}{l}-0.008 \\
(0.016)\end{array}$ & $\begin{array}{l}-0.007 \\
(0.016)\end{array}$ & $\begin{array}{c}-0.029^{* *} \\
(0.015)\end{array}$ & $\begin{array}{c}-0.032^{* *} \\
(0.015)\end{array}$ & $\begin{array}{c}-0.032^{* *} \\
(0.015)\end{array}$ & $\begin{array}{l}-0.008 \\
(0.019)\end{array}$ & $\begin{array}{l}-0.008 \\
(0.019)\end{array}$ & $\begin{array}{l}-0.031^{*} \\
(0.018)\end{array}$ & $\begin{array}{l}-0.031 \\
(0.019)\end{array}$ & $\begin{array}{l}-0.032^{*} \\
(0.019)\end{array}$ \\
\hline Age squared & $\begin{array}{c}0.000 \\
(0.000)\end{array}$ & $\begin{array}{c}0.000 \\
(0.000)\end{array}$ & $\begin{array}{l}0.00 *^{*} \\
(0.000)\end{array}$ & $\begin{array}{l}0.000^{*} \\
(0.000)\end{array}$ & $\begin{array}{l}0.000^{*} \\
(0.000)\end{array}$ & $\begin{array}{c}0.000 \\
(0.000)\end{array}$ & $\begin{array}{c}0.000 \\
(0.000)\end{array}$ & $\begin{array}{l}0.000^{* *} \\
(0.000)\end{array}$ & $\begin{array}{l}0.000^{* *} \\
(0.000)\end{array}$ & $\begin{array}{l}0.000^{* *} \\
(0.000)\end{array}$ & $\begin{array}{c}0.000 \\
(0.000)\end{array}$ & $\begin{array}{c}0.000 \\
(0.000)\end{array}$ & $\begin{array}{l}0.000^{*} \\
(0.000)\end{array}$ & $\begin{array}{l}0.000^{*} \\
(0.000)\end{array}$ & $\begin{array}{l}0.000^{*} \\
(0.000)\end{array}$ \\
\hline $\begin{array}{l}\text { Martial status/parental edu/urban } \\
\text { controls? }\end{array}$ & No & No & Yes & Yes & Yes & No & No & Yes & Yes & Yes & No & No & Yes & Yes & Yes \\
\hline District council controls? & No & No & No & Yes & Yes & No & No & No & Yes & Yes & No & No & No & Yes & Yes \\
\hline Constant & $\begin{array}{l}0.870^{* *} \\
(0.346)\end{array}$ & $\begin{array}{l}0.841^{* *} \\
(0.351)\end{array}$ & $\begin{array}{c}1.305 * * * \\
(0.357)\end{array}$ & $\begin{array}{c}1.466 * * * \\
(0.349)\end{array}$ & $\begin{array}{c}1.442^{* * *} \\
(0.345)\end{array}$ & $\begin{array}{l}0.863 * * \\
(0.378)\end{array}$ & $\begin{array}{l}0.845^{* *} \\
(0.382)\end{array}$ & $\begin{array}{c}1.445^{* * *} \\
(0.359)\end{array}$ & $\begin{array}{c}1.650^{* * *} \\
(0.372)\end{array}$ & $\begin{array}{c}1.632^{* * *} \\
(0.367)\end{array}$ & $\begin{array}{l}0.849^{*} \\
(0.471)\end{array}$ & $\begin{array}{l}0.835^{*} \\
(0.473)\end{array}$ & $\begin{array}{c}1.472 * * * \\
(0.443)\end{array}$ & $\begin{array}{c}1.620^{* * *} \\
(0.461)\end{array}$ & $\begin{array}{c}1.624^{* * *} \\
(0.460)\end{array}$ \\
\hline Observations & 1,875 & 1,875 & 1,871 & 1,871 & 1,871 & 1,563 & 1,563 & 1,563 & 1,563 & 1,563 & 1,291 & 1,291 & 1,291 & 1,291 & 1,291 \\
\hline R-squared & 0.026 & 0.028 & 0.064 & 0.097 & 0.097 & 0.032 & 0.034 & 0.075 & 0.116 & 0.117 & 0.029 & 0.030 & 0.070 & 0.124 & 0.126 \\
\hline F-test:tert & & & & & 0.0132 & & & & & 0.301 & & & & & 0.119 \\
\hline Prob > F:tert & & & & & 0.909 & & & & & 0.584 & & & & & 0.730 \\
\hline F-test:matric & & & & & 0.0940 & & & & & 0.0364 & & & & & 0.214 \\
\hline Prob > F:matric & & & & & 0.759 & & & & & 0.849 & & & & & 0.644 \\
\hline F-test:incomsec & & & & & 0.00681 & & & & & 0.147 & & & & & 0.333 \\
\hline Prob > F:incs & & & & & 0.934 & & & & & 0.702 & & & & & 0.564 \\
\hline
\end{tabular}


ECO/WKP(2013)13

Table 3b. Employment regressions - LPM, weighted - pupil/teacher ratio

\begin{tabular}{|c|c|c|c|c|c|c|c|c|c|c|c|c|c|c|c|}
\hline & $\begin{array}{l}(1) \\
\text { all } \\
\end{array}$ & $\begin{array}{l}(2) \\
\text { all } \\
\end{array}$ & $\begin{array}{l}(3) \\
\text { all } \\
\end{array}$ & $\begin{array}{l}(4) \\
\text { all } \\
\end{array}$ & $\begin{array}{l}(5) \\
\text { all } \\
\end{array}$ & $\begin{array}{c}\text { (6) } \\
\text { samedc }\end{array}$ & $\begin{array}{c}(7) \\
\text { samedc }\end{array}$ & $\begin{array}{c}\text { (8) } \\
\text { samedc }\end{array}$ & $\begin{array}{c}\text { (9) } \\
\text { samedc }\end{array}$ & $\begin{array}{c}(10) \\
\text { samedc }\end{array}$ & $\begin{array}{c}(11) \\
\text { nevermove } \\
\end{array}$ & $\begin{array}{c}(12) \\
\text { nevermove } \\
\end{array}$ & $\begin{array}{c}(13) \\
\text { nevermove } \\
\end{array}$ & $\begin{array}{c}(14) \\
\text { nevermove } \\
\end{array}$ & $\begin{array}{c}(15) \\
\text { nevermove } \\
\end{array}$ \\
\hline Incomplete Secondary & $\begin{array}{l}-0.035 \\
(0.038)\end{array}$ & $\begin{array}{c}-0.032 \\
(0.038)\end{array}$ & $\begin{array}{l}-0.047 \\
(0.037)\end{array}$ & $\begin{array}{l}-0.047 \\
(0.036)\end{array}$ & $\begin{array}{l}-0.134 \\
(0.093)\end{array}$ & $\begin{array}{r}-0.050 \\
(0.040)\end{array}$ & $\begin{array}{l}-0.050 \\
(0.040)\end{array}$ & $\begin{array}{l}-0.065 * \\
(0.039)\end{array}$ & $\begin{array}{l}-0.068^{*} \\
(0.037)\end{array}$ & $\begin{array}{l}-0.196^{* *} \\
(0.086)\end{array}$ & $\begin{array}{r}-0.030 \\
(0.047)\end{array}$ & $\begin{array}{r}-0.030 \\
(0.047)\end{array}$ & $\begin{array}{l}-0.053 \\
(0.046)\end{array}$ & $\begin{array}{r}-0.059 \\
(0.045)\end{array}$ & $\begin{array}{l}-0.261^{* * *} \\
(0.094)\end{array}$ \\
\hline Matric & $\begin{array}{l}0.063 \\
(0.046)\end{array}$ & $\begin{array}{l}0.064 \\
(0.046)\end{array}$ & $\begin{array}{l}0.043 \\
(0.045)\end{array}$ & $\begin{array}{l}0.052 \\
(0.045)\end{array}$ & $\begin{array}{l}0.066 \\
(0.091)\end{array}$ & $\begin{array}{l}0.088^{*} \\
(0.048)\end{array}$ & $\begin{array}{l}0.087^{*} \\
(0.048)\end{array}$ & $\begin{array}{l}0.061 \\
(0.050)\end{array}$ & $\begin{array}{l}0.080 \\
(0.048)\end{array}$ & $\begin{array}{l}0.020 \\
(0.112)\end{array}$ & $\begin{array}{l}0.092 \\
(0.061)\end{array}$ & $\begin{array}{l}0.095 \\
(0.061)\end{array}$ & $\begin{array}{l}0.063 \\
(0.061)\end{array}$ & $\begin{array}{c}0.085 \\
(0.060)\end{array}$ & $\begin{array}{l}0.048 \\
(0.131)\end{array}$ \\
\hline Tertiary & $\begin{array}{c}0.162 * * * \\
(0.033)\end{array}$ & $\begin{array}{c}0.163 * * * \\
(0.033)\end{array}$ & $\begin{array}{c}0.147 * * * \\
(0.042)\end{array}$ & $\begin{array}{c}0.155^{* * * *} \\
(0.042)\end{array}$ & $\begin{array}{l}-0.064 \\
(0.111)\end{array}$ & $\begin{array}{c}0.173 * * * \\
(0.038)\end{array}$ & $\begin{array}{c}0.173^{* * *} \\
(0.038)\end{array}$ & $\begin{array}{c}0.138 * * * \\
(0.043)\end{array}$ & $\begin{array}{c}0.154^{* * *} \\
(0.044)\end{array}$ & $\begin{array}{l}-0.091 \\
(0.120)\end{array}$ & $\begin{array}{c}0.190^{* * * *} \\
(0.047)\end{array}$ & $\begin{array}{c}0.191^{* * * *} \\
(0.047)\end{array}$ & $\begin{array}{c}0.149 * * * \\
(0.051)\end{array}$ & $\begin{array}{c}0.179 * * * \\
(0.056)\end{array}$ & $\begin{array}{l}-0.115 \\
(0.156)\end{array}$ \\
\hline Pupil teacher ratio - closest high school & $(0.033)$ & $\begin{array}{l}(.033) \\
-0.002 \\
(0.002)\end{array}$ & $\begin{array}{l}(.04) \\
-0.002 \\
(0.001)\end{array}$ & $\begin{array}{c}(.0 .04) \\
-0.002 \\
(0.001)\end{array}$ & $\begin{array}{l}-0.003^{*} \\
(0.002)\end{array}$ & & $\begin{array}{l}-0.002 \\
(0.002)\end{array}$ & $\begin{array}{l}-0.002 \\
(0.002)\end{array}$ & $\begin{array}{l}-0.001 \\
(0.002)\end{array}$ & $\begin{array}{l}-0.003^{*} \\
(0.002)\end{array}$ & & $\begin{array}{c}0.000 \\
(0.002)\end{array}$ & $\begin{array}{c}0.000 \\
(0.002)\end{array}$ & $\begin{array}{c}0.001 \\
(0.002)\end{array}$ & $\begin{array}{l}-0.001 \\
(0.002)\end{array}$ \\
\hline Incomplete Secondary x matric score & $\begin{array}{l}0.000 \\
(0.000)\end{array}$ & $\begin{array}{l}0.000 \\
(0.000)\end{array}$ & $\begin{array}{l}0.000^{*} \\
(0.000)\end{array}$ & $\begin{array}{l}0.000^{* *} \\
(0.000)\end{array}$ & $\begin{array}{l}0.000 * * \\
(0.000)\end{array}$ & $\begin{array}{l}0.000 \\
(0.000)\end{array}$ & $\begin{array}{l}0.000 \\
(0.000)\end{array}$ & $\begin{array}{l}0.000^{* *} \\
(0.000)\end{array}$ & $\begin{array}{l}0.000 * * \\
(0.000)\end{array}$ & $\begin{array}{l}0.000^{* *} \\
(0.000)\end{array}$ & $\begin{array}{c}0.000 \\
(0.000)\end{array}$ & $\begin{array}{l}0.000 \\
(0.000)\end{array}$ & $\begin{array}{l}0.000^{*} \\
(0.000)\end{array}$ & $\begin{array}{l}0.000^{*} \\
(0.000)\end{array}$ & $\begin{array}{l}0.000 * * \\
(0.000)\end{array}$ \\
\hline Matric $x$ matric score & & & & & $\begin{array}{l}0.003 \\
(0.003)\end{array}$ & & & & & $\begin{array}{l}0.004 \\
(0.003)\end{array}$ & & & & & $\begin{array}{l}0.006^{* *} \\
(0.003)\end{array}$ \\
\hline Tertiary x matric score & & & & & $\begin{array}{r}-0.000 \\
(0.003)\end{array}$ & & & & & $\begin{array}{c}0.002 \\
(0.003)\end{array}$ & & & & & $\begin{array}{l}0.001 \\
(0.004)\end{array}$ \\
\hline Age & -0.007 & -0.008 & $-0.024^{*}$ & $-0.026^{*}$ & $-0.026^{*}$ & -0.008 & -0.008 & $-0.030^{* *}$ & $-0.033^{* *}$ & $-0.033^{* *}$ & -0.008 & -0.009 & $-0.033^{*}$ & $-0.033^{*}$ & $-0.033^{*}$ \\
\hline & $(0.015)$ & $(0.015)$ & $(0.015)$ & $(0.014)$ & $(0.014)$ & $(0.016)$ & $(0.016)$ & $(0.015)$ & $(0.015)$ & $(0.014)$ & $(0.019)$ & $(0.019)$ & $(0.018)$ & $(0.019)$ & $(0.019)$ \\
\hline Age squared & $\begin{array}{c}0.000 \\
(0.000)\end{array}$ & $\begin{array}{c}0.000 \\
(0.000)\end{array}$ & $\begin{array}{l}0.000^{*} \\
(0.000)\end{array}$ & $\begin{array}{l}0.000^{* *} \\
(0.000)\end{array}$ & $\begin{array}{l}0.000^{* *} \\
(0.000)\end{array}$ & $\begin{array}{c}0.000 \\
(0.000)\end{array}$ & $\begin{array}{c}0.000 \\
(0.000)\end{array}$ & $\begin{array}{l}0.000^{* *} \\
(0.000)\end{array}$ & $\begin{array}{l}0.000^{* *} \\
(0.000)\end{array}$ & $\begin{array}{l}0.000^{* *} \\
(0.000)\end{array}$ & $\begin{array}{c}0.000 \\
(0.000)\end{array}$ & $\begin{array}{l}0.000 \\
(0.000)\end{array}$ & $\begin{array}{l}0.000^{*} \\
(0.000)\end{array}$ & $\begin{array}{l}0.000^{*} \\
(0.000)\end{array}$ & $\begin{array}{l}0.000^{* *} \\
(0.000)\end{array}$ \\
\hline Martial status/parental edu/urban controls? & No & No & Yes & Yes & Yes & No & No & Yes & Yes & Yes & No & No & Yes & Yes & Yes \\
\hline District council controls ? & No & No & No & Yes & Yes & No & No & No & Yes & Yes & No & No & No & Yes & Yes \\
\hline Constant & $0.870^{* *}$ & $0.946^{* * *}$ & $1.395^{* * *}$ & $1.520^{* * *}$ & $1.530^{* * *}$ & $0.863^{* *}$ & $0.933^{* *}$ & $1.516^{* * *}$ & $1.669^{* * *}$ & $1.722^{* * *}$ & $0.849^{*}$ & $0.855^{*}$ & $1.487^{* * *}$ & $1.621^{* * *}$ & $1.668^{* * *}$ \\
\hline $\begin{array}{l}\text { Observations } \\
\text { R-squared }\end{array}$ & $(0.346)$ & $(0.352)$ & $(0.353)$ & $(0.332)$ & $(0.349)$ & $(0.378)$ & $(0.385)$ & $(0.358)$ & $(0.359)$ & $(0.362)$ & $(0.471)$ & $(0.479)$ & $(0.445)$ & $(0.452)$ & $(0.464)$ \\
\hline $\begin{array}{l}\text { R-squared } \\
\text { F-test:tert }\end{array}$ & & & & 1,871 & 1,871 & 1,563 & 1,563 & 1,563 & 1,563 & 1,563 & 1,291 & 1,291 & 1,291 & 1,291 & 1,291 \\
\hline Prob $>$ F:tert & & & & 0.100 & 0.103 & 0.032 & 0.036 & 0.076 & 0.118 & 0.121 & 0.029 & 0.031 & 0.071 & 0.125 & 0.131 \\
\hline F-test:matric & & & & & 2.607 & & & & & 2.469 & & & & & 4.406 \\
\hline Prob > F:matric & & & & & 0.107 & & & & & 0.117 & & & & & 0.0366 \\
\hline F-test:incomsec & & & & & 1.741 & & & & & 0.302 & & & & & 0.00207 \\
\hline Prob $>$ F:incs & & & & & 0.188 & & & & & 0.583 & & & & & 0.964 \\
\hline
\end{tabular}




\section{Robustness/additional checks}

\subsection{The school quality measures}

In this section we check the sensitivity of the results to different aggregations of the school quality measures and check whether pupil/teacher ratios are not proxying for matric results and vice versa. We tested two additional school quality constructs - the average matric exemption score and pupil/teacher ratio of all secondary schools in an $8 \mathrm{~km}$ radius of the individuals' household and the actual school the respondent attended. The reason we investigate the $8 \mathrm{~km}$ radius measure is that while most learners attend a school in their immediate neighbourhood, they do not necessarily attend the closest school. The $8 \mathrm{~km}$ radius measure provides a better measure of the average characteristics of schools in the respondents' neighbourhood. We find similar, albeit slightly larger coefficients, when the $8 \mathrm{~km}$ radius measure is used. The actual school attended by the respondent could be argued to reduce measurement error on the quality measures. However, only 400 of our 1875 sample respondents have details on the school they actually attended. The school quality measures from the models using actual school attended are close to zero and statistically insignificant. It is not clear whether this is a function of the sample or reflects a difference in substantive findings.

It is possible that the school quality measures are significantly correlated with earnings, not because the specific quality measure actually affects earnings, but because it signals another mechanism that is correlated with matric exemption score or pupil/teacher ratio (Case and Yogo, 1999). To test this we include both the pupil/teacher ratio and matric score variables in the same regression. The respective coefficients are not significantly affected. This signals that the school quality measures are not proxying for each other.

\subsection{Results across different samples}

We produced similar regressions for a sample of African females 32-65 in 2008. None of the quality measures were statistically significant and the school quality coefficients were small. It is possible that school quality affects the number of hours female workers are employed and not the wage. Case and Yogo (1999) also found less of an effect of school quality on female earnings although they found larger effects for employment within the female group.

We checked whether the results in our analysis were sensitive to the choice of age groups. In particular, we were interested to see whether restricting the sample to 25-35, the age range used in Case and Yogo (1999) increased the coefficient estimate of the relationship between female employment and school quality. We found no effect. In fact, increasing the age range reduced the size of the quality estimates in all regressions.

\subsection{Discussion and conclusions}

In this paper we investigate the impact of including measures of school quality on labour market premiums to different levels of education. We use the matric exemption score and pupil/teacher ratio of the respondents' closest school as a proxy for the quality of education in the respondents' school. Our sample is restricted to African males who would have completed their education under apartheid in an attempt to reduce the potential bias of endogenous school choice.

We find that the employment and earnings premiums to education level are particularly robust to the inclusion of quality measures. In fact, we find that the coefficients on the education category variables are only reduced marginally when we control for school quality, parental education and location of birth, among other things. This is unlike the finding of Hertz (1993) whose estimates of the return to education 
halve when omitted variables are controlled for using family fixed effects. Note however that Hertz's method controls for all time invariant unobserved characteristics that are common within households and may therefore be controlling for additional omitted factors that affect labour market success. He also uses a continuous measure of educational attainment rather than categories which may account for some of the difference.

There is a significant relationship between the matric score and pupil/teacher ratio of the respondent's closest school and earnings, but no significant relationship with employment. On average, increasing the matric exemption score by $10 \%$ increases earnings by $8 \%$ and decreasing the pupil/teacher ratio by one learner is associated with a $1 \%$ increase in earnings. The interaction terms in the final specification show that the relationship between earnings and school quality differs across the educational attainment categories. The earnings of those with primary and tertiary appear most affected by school quality. One possible reason that those with primary are likely to be strongly affected is that, in a good-quality school, those leaving with primary education still manage to achieve a basic degree of literacy and numeracy, while those in poor-quality schools are illiterate and or innumerate. This difference between being illiterate or not or innumerate or not could explain the large quality effect for those with primary. Indeed, Moll (1998) shows that many African learners only achieve basic computational (and literacy to a lesser degree) skills in secondary school. For those with tertiary education, school quality may determine the type of matric attained and hence what type of tertiary education the individual is eligible for. The labour market reward for a degree versus a diploma differs fairly substantially and could account for the average wage difference (Branson, Leibbrandt and Zuze, 2009).

The fact that there is less of an apparent relationship between employment and school quality, but a strong relationship with earnings, could signal that the difference in school quality is differentiating workers skills in ways that are not immediately evident to an employer, but materialise once the individual is employed. We see that the quality measure coefficient is reduced when the sample is extended to include younger workers, which would support this hypothesis. Note however that there is still an indirect effect of quality on employment via educational attainment. Those in better-quality schools get more education on average hence there is a positive probability-of-employment effect, but indirectly, via having stayed in school for longer.

We find a pupil/teacher ratio affect that is much larger than the one found by Case and Yogo (1999). They find that a 10 learner increase in the pupil/teacher ratio leads to a $1 \%$ increase in earnings, compared to our $10 \%$ increase. Unfortunately it is not clear whether these two results are consistent as the sample and method differ substantially. Their sample group is younger - 24-3 year olds - while we focus on prime age (32-64) adults. If replicate our results for their age sample, the estimates are far closer but still larger. Note however that decreasing the age of our sample means that our respondents would no longer have been educated under apartheid and hence they would not have been subject to the same restrictions. Case and Yogo also use a different method. They use magisterial district measures of school quality and a two-step procedure first to estimate educational attainment and then earnings.

The results are fairly robust across the different samples, however there are some marginal differences worth noting. First, the educational attainment coefficients increase a bit when the sample is restricted to respondents who have never moved. Second, the size of the quality measures coefficient decreases in this restricted sample. We saw in Table 1 that average educational attainment is higher in the full sample, within each school quality category, reflecting that the average educational attainment of those who move is higher than the average educational attainment of those who do not move. We also saw that the proportion of the sample lost when moving from the full sample to the never moved sample increased with higher school quality category. From this it appears that there is a relationship between school quality and moving. School quality may be part of what enables respondents to move to find employment in areas with 
better labour market outcomes. Whether this relationship is via an increase in educational attainment or directly has not been interrogated in this paper, but would be interesting for further work.

These results are not positive for progress within South Africa's education system. Access to quality education is particularly unequal with the majority of learners receiving education well below an acceptable standard as evidenced in the low success on national and international tests. In addition, while there has been a rapid increase in educational attainment among Africans, the labour market rewards tertiary, in particular, with an extremely high premium. Yet the growth in tertiary graduates has failed to keep pace. This is partly because the number of matriculants with exemption has lagged behind, reflecting the average poor quality schooling. Thus those attending poor quality schools are not only less likely to attain the higher levels of education required for more certain labour market success, but the direct relationship between school quality and earnings implies that those in low quality schools are directly disadvantaged in terms of their earnings once they find work. 


\section{BIBLIOGRAPHY}

Branson, N. and M. Leibbrandt (2012). "Educational Attainment and Labour Market Outcomes in South Africa, 1994-2010", OECD working paper, forthcoming.

Branson, N., Lam, D. and T.L. Zuze (2012), "Education: Analysis of the NIDS Wave 1 and 2 Datasets", National Income Dynamics Study Discussion Papers, 2012/4, Place: Publisher (SALDRU).

Branson, N., Leibbrandt, M. and T. L. Zuze (2009), "The demand for tertiary education in South Africa", CHET Report.

Burger, C. and S. van der Berg (2011), "Modelling cognitive skills, ability and school quality to explain labour market earnings differentials", Stellenbosch Economic Working Papers, 08/11.

Card, D. and A. B. Krueger (1992), "School Quality and Black-White Relative Earnings: A Direct Assessment", Quarterly Journal of Economics, Vol. 107, pp. 151-20.

Card, D. and A. B. Krueger (1999), "Labor market effects of school quality: theory and evidence", NBER Working Papers, 5450.

Case, A. and A. Deaton (1999), "School Inputs and Educational Outcomes in South Africa", The Quarterly Journal of Economics, pp. 1047-1084.

Case, A. and M. Yogo (1999), "Does school quality matter? Returns to education and the characteristics of schools in South Africa", NBER Working Papers, 7399.

Chamberlain, D. and S. van der Berg (2002), "Earnings functions, labour market discrimination and quality of education in South Africa", Stellenbosch Economic Working Papers, 2 / 2002.

Equal Education (2009), "Comment on regulations relating to the prohibition of the payment of unauthorised remuneration of the giving of financial benefit or benefit in kind to certain state employees",Washington Square, Capital Drive, Tembani, Khayelitsha.

Gibbon, T., Muller J. and H. Nel (2012), "Higher education and an expanded post-school education system", in Perold, H., Cloete, N., and J. Papier (eds), Shaping the future of South Africa's youth, African Minds, Cape Town.

Government Notice no. 1272 and 1354.

Heckman, J., Layne-Farrar A. and P. Todd (1996), "Human Capital Pricing Equations with an Application to Estimating the Effect of Schooling Quality on Earnings", The Review of Economics and Statistics, Vol. 78(4), pp. 562-610.

Hertz, T. (2003), "Upward Bias in the Estimated Returns to Education: Evidence from South Africa", The American Economic Review, Vol. 93(4), pp. 1354-1368.

Keswell, M. and L. Poswell (2004), "Returns to education in South Africa: a retrospective sensitivity analysis of the available evidence", South African Journal of Economics Vol. 72(4). 
Moll, P. (1996), “The collapse of primary schooling returns in South Africa, 1960-1990”, Oxford Bulletin of Economics and Statistics, 58, pp. 185-209.

Moll, P. (1998), "Primary Schooling, Cognitive Skills and Wages in South Africa", Economica, Vol. 65(258), pp. 263-284.

Southern Africa Labour and Development Research Unit (2012), National Income Dynamics Study 2008, Wave 1. Version 4.1, Southern Africa Labour and Development Research Unit, DataFirst, 2012, Cape Town.

Southern Africa Labour and Development Research Unit (2012), National Income Dynamics Study 20102011, Wave 2. Version 1, Southern Africa Labour and Development Research Unit, DataFirst, Cape Town.

Spaull, N. (2012), "Poverty and Privilege: Primary School Inequality in South Africa”, International Journal of Educational Development, pp. 1-12.

United Nations Educational Scientific and Cultural Organization (2011), 2011 EFA Global Monitoring Report, UNESCO, Paris. 


\section{WORKING PAPERS}

The full series of Economics Department Working Papers can be consulted at www.oecd.org/eco/workingpapers/

1020. Do policies that reduce unemployment raise its volatility? Evidence from OECD countries (January 2013) by Alain de Serres and Fabrice Murtin

1019. Slovakia: A catching up euro area member in and out of the crisis (January 2013) by Jarko Fidrmuc, Caroline Klein, Robert Price and Andreas Wörgötter

1018. Improving the fiscal framework to enhance growth in an era of fiscal consolidation in Slovakia (January 2013) by Caroline Klein, Robert Price and Andreas Wörgötter

1017. Investing efficiently in education and active labour market policies in Slovakia (January 2013) by Caroline Klein

1016. The performance of road transport infrastructure and its links to policies (January 2013) by Henrik Braconier, Mauro Pisu and Debra Bloch

1015. The US labour market recovery following the great recession (January 2013) by Wendy Dunn

1014. Why do Russian firms use fixed-term and agency work contracts? (December 2012) by Larisa Smirnykh and Andreas Wörgötter

1013. The Equity implications of fiscal consolidation (December 2012) by Lukasz Rawdanowicz, Eckhard Wurzel and Ane Kathrine Christensen

1012. The Dutch labour market: preparing for the future (December 2012) by Mathijs Gerritsen and Jens Høj

1011. Reforming policies for the business sector to harvest the benefits of globalisation in the Netherlands

(December 2012) by Mathijs Gerritsen and Jens Høj

1010. Health care reform and long-term care in the Netherlands (December 2012) by Erik Schut, Stéphane Sorbe and Jens Høj

1009. Enhancing the inclusiveness of the labour market in Belgium (December 2012) by Jens Høj

1008. Reducing poverty in Estonia through activation and better targeting (December 2012) by Sarah Flèche and Artur Radziwill

1007. Matching skills and jobs in Estonia (December 2012) by Lilas Demmou

1006. Debt and macroeconomic stability: An overview of the literature and some empirics (December 2012) by Douglas Sutherland and Peter Hoeller 
1005. Debt and macroeconomic stability: Debt and the business cycle

(December 2012) by Volker Ziemann

1004. Debt and macroeconomic stability: Case studies

(December 2012) by Rossana Merola

1003. Debt and macroeconomic stability

(December 2012) by Douglas Sutherland, Peter Hoeller, Rossana Merola and Volker Ziemann

1002. Reducing greenhouse gas emissions in a cost effective way in Switzerland.

(December 2012) by Anita Wölfl and Patrizio Sicari

1001. Strengthening innovation in the United States

(November 2012) by David Carey, Christopher Hill and Brian Kahin

1000. Long-term growth scenarios

(January 2013) by Åsa Johansson, Yvan Guillemette, Fabrice Murtin, David Turner,

Giuseppe Nicoletti, Christine de la Maisonneuve, Philip Bagnoli, Guillaume Bousquet and

Francesca Spinelli

999. Selected aspects of household savings in Germany - evidence from micro-data

(November 2012) by Christina Kolerus, Isabell Koske and Felix Hüfner

998. Improving the tax system in Indonesia

(November 2012) by Jens Arnold

997. Unleashing business innovation in Canada

(November 2012) by Alexandra Bibbee

996. Public policy and resource allocation: evidence from firms in OECD countries

(October 2012) by Dan Andrews and Federico Cingano

995. Promoting SME development in Indonesia

(October 2012) by Annabelle Mourougane

994. Portugal: Rebalancing the economy and returning to growth through job creation and better capital allocation.

(October 2012) by Álvaro Pina and Ildeberta Abreu

993. Public debt, economic growth and nonlinear effects: Myth or reality?

(October 2012) by Balázs Égert

992. Choosing the pace of fiscal consolidation

(September 2012) by Lukasz Rawdanowicz

991. Tertiary education developing skills for innovation and long-term growth in Canada

(September 2012) by Calista Cheung, Yvan Guillemette and Shahrzad Mobasher-Fard

990. Trade and product market policies in upstream sectors and productivity in downstream sectors: firm-level evidence from China

(September 2012) by Maria Bas and Orsetta Causa 